\title{
MALVARLIĞININ TERKI SURETIYLE KONKORDATODA KONKORDATO TASFIYE MEMURU
}

The Concordat Liquidators with the Composition with the Creditors the Transfer of the Assets

Cenk AKÍL*

\section{ÖZET}

Konkordato tasfiye memuru ya da memurları konkordato talebini müzakere ederek kabul veya reddine ilişkin olarak oy kullanan alacaklılar toplantısı tarafindan seçilir. Tasfiye memurları, kamu menfaatlerinin temini bağlamında görev yapan birer kamu görevlisi olup; İ̈K m. 309/a, II uyarınca icra mahkemesinin, alacaklıların seçime ilişkin kararını onaylamasıyla göreve başlar. Tasfiye memurları ceza kanunu anlamında da kamu görevlisi sayılır. Tasfiye memurları alacaklılar kurulunun nezaret ve denetimi altında çalışarak, masa mallarının muhafazası, paraya çevrilmesi ve malların devri için gerekli işlemleri yapar. Tasfiye memurlarının malvarlığının paraya çevrilmesine ilişkin karar ve işlemlerine karşı, öğrenmeden itibaren yedi gün içinde alacaklılar kuruluna itirazda bulunulabilir. Bunun dışında kalan kararlarına karşı ise icra mahkemesi nezdinde şikâyet yoluna başvurulabilir.

Anahtar Sözcükler: Konkordato, malvarlığının terki suretiyle konkordato, konkordato tasfiye memuru, alacaklılar kurulu.

*Dr., (akilcenk@hotmail.com). 


\begin{abstract}
The liquidator or liquidators of concordat are elected by the meeting of creditors who voted regarding to the acceptance or rejection of the application of the concordat by debating the application. The liquidators are public officials who serve in the context of obtainment of public interest and they begin to work with the enforcement court's confirmation of the decision of the creditors regarding the election pursuant to the Article 309/a, Paragrafh II. The liquidators are assumed as public officials in point of the Criminal Code as well. The liquidators maket the legal transactions necessary for the maintenance, encashment and transfer of the assets of the estate by working under the supervision and auditing of the board of creditors. It can be objected to the decisions and transactions of the liquidators regarding the encashment of the assets, within seven days beginnig from the learning to the board of creditors. It can be remonstrated against to the decisions of the liquidators except this with the enforcment court.
\end{abstract}

Keywords: Concordat, composition with the creditors for the transfer of the assets, concordat liquidator, board of creditors.

\title{
GíRiş
}

Borçlu, piyasa şartlarının uygun olmaması, işlerinin öngördüğü şekilde gitmemesi veya tahminlerinde yanılması gibi sebeplerle iktisadi açıdan güçlükle karşılaşmış ve elinde olmayan nedenlerle mali durumu bozulmuş olabilir. İşe, bu tip borçluları yapılacak olası icra ve iflâs takiplerinden korumak ve bu suretle ekonomik varlıklarını sürdürmelerine olanak tanımak amaciyla konkordato kurumu kabul edilmiştir ${ }^{1}$. İcra ve İflâs Kanunu'nda düzenlenen adli (resmi) konkordato (İ̈K m. 285-3091); adi konkordato, iflâstan sonra konkordato ve malvarlığının terki suretiyle konkordato şeklinde yapılabilir².

${ }^{1}$ Ulukap1, s. 8 vd; Altay, s. 7 vd. Konkordatodaki menfaat sahipleri hakkında bkz. Muşul, s. 186-187.

${ }^{2}$ Erdönmez, s. 199. Adi konkordato ile malvarlığının terki suretiyle konkordato ayırımının temelinde her iki konkordatonun gerçekleştirmeye yönelmiş oldukları amaçların birbirinden farklılık göstermesi yatar. Adi konkordatoda esas itibarıyla borçlunun işletmesinin başında kalmak suretiyle, ekonomik durumunu düzeltmesine ve varlığını devam ettirmesine uygun 
Malvarlığının terki suretiyle konkordato, hukukumuza 30.07.2003 tarih ve 4949 sayılı Kanun ile girmiş bir konkordato türü olup; İcra ve İflâs Kanunu'nun 309a-3091 maddeleri ile İcra ve İflâs Kanunu Yönetmeliği'nin 106-107. maddelerinde düzenlenmiştir.

İcra ve İflâs Kanunu'nun 309/a ilâ 309/1 maddelerinde düzenlenen malvarlığının terki suretiyle konkordato değişik şekillerde gerçekleştirilebilir. Bu bağlamda alacaklılara borçlunun malvarlığı üzerinde tasarruf etme yetkisi verilebileceği gibi bu malların tamamını ya da bir kısmını üçüncü kişiye devretme yetkisi de verilebilir. Konkordato teklifi alacaklılarca kabul edilip konkordato mahkemece tasdik edilince borçlunun malvarlığ malvarlığı üzerinde tasarrufta bulunma yetkisi, alacaklılara geçer ${ }^{3}$. Alacaklılar, bu tasarruf yetkisini seçecekleri konkordato tasfiye memurları ve alacaklılar kurulu aracılığıyla kullanır. İcra mahkemesinin seçilmelerine ilişkin alacaklılar kararını onaylamasından sonra göreve başlayan tasfiye memurları, borçlunun mallarını iflâs tasfiyesine benzer bir şekilde tasfiye $\operatorname{eder}^{4}$ ve elde edilen parayı alacaklılara dağıtır. Malvarlığının terki suretiyle konkordatonun diğer bir türünde ise borçlunun malvarlığının tamamı veya bir kısmı, alacaklılara genellikle belli bir vadeye yayılan taksitler halinde ödeme yapılması karşılığında, bir üçüncü kişiye devredilir ${ }^{5}$. Malvarlığının terki suretiyle konkordatonun borçlunun aktifleriyle yeni bir şirket kurularak bu şirketin paylarının alacaklılara dağıtılması suretiyle gerçekleştirilmesi de mümkündür ${ }^{6}$.

Malvarlığının terki suretiyle konkordato yapılmasında hem borçlunun hem de alacaklıların menfaati vardır. Zira böyle bir konkordatonun

bir ortamın yaratılmasına çalışılırken; malvarlığının terki suretiyle konkordatoda, borçlunun malvarlığının aktiflerinin tamamı ya da bir kısmı üzerindeki tasarruf yetkisinin iflâsa nazaran daha yumuşak ve daha esnek bir rejim içinde gerçekleştirilecek olan tasfiye amacı ile sınırlı olarak, alacaklılara intikal ettirilmesi hedeflenir. Bkz. Tanrıver, S.: 4949 Sayılı İcra ve İflas Kanunu'nda Değişiklik Yapılmasına Dair Kanun'un Adi Konkordato ile İlgili Hükümlerde Getirmiş Olduğu Değişikliklerin Tespiti ve Değerlendirilmesi (TBBD 2004/51), s. 67.

${ }^{3}$ Kuru, s. 1336

${ }^{4}$ Malvarlığının terki suretiyle konkordatonun iflâs prosedürüne nazaran arz ettiği en önemli fayda, aktifin paraya çevrilmesi konusunda zaman ve çeşit bakımından gösterdiği esnekliktir. Bkz. İyilikli, s. 593.

${ }^{5} \mathrm{Kuru} /$ Ramazan/Y1lmaz, s. 654-655.

${ }^{6}$ Geniş bilgi için bkz. Ercan, s. 111 vd., 117 vd. 
gerçekleştirilmesi hem borçluyu iflâs etmekten ve iflâsın kamu hukuku bakımından sonuçlarından kurtararak $^{7}$ ticari saygınlığının daha fazla zedelenmesine engel olur; hem de aktiflerinin tasfiyesi sonucunda elde edilen değerden karşılanamayan alacak kesimleri için borç ödemeden aciz belgesi düzenlenmesini önler. $\mathrm{Bu}$ konkordato türü alacaklıların da yararınadır. Çünkü alacaklılar bu konkordatoya dayalı olarak gerçekleştirilecek tasfiyeden iflâs tasfiyesine nazaran daha fazla oranda pay alabilecektir ${ }^{8}$.

Malvarlığının terki suretiyle konkordatoda alacaklılar, haklarını tasfiye memurları ve alacaklılar kurulu aracılığıyla kullanırlar. Alacaklılar toplantısı tarafindan seçilen alacaklılar kurulu ile tasfiye memurları, bu konkordatonun zorunlu organlarıdır (İ̈K m. 309a, II). Bu organların üyelerinin belirlenmesi ve yetkileri, malvarlığının terki suretiyle konkordatonun zorunlu içeriğinden sayılmıştır (İ̈K m. 309b, I/2) ${ }^{9}$.

\section{HUKUKÎ NİTELİĞİ}

Öğretide tasfiye memurlarının hukukî niteliği belirlenirken özellikle konkordato komiseri ile iflâs idaresinin hukukî niteliğinden yararlanıldığı göze çarpmaktadır. Nitekim, İsviçre hukuk öğretisinde ileri sürülen bir görüş ${ }^{10}$ konkordato tasfiye memurlarının hukukî niteliğinin konkordato komiseri ile aynı olduğunu savunurken hâkim görüş ${ }^{11}$ bu konuda iflâs idaresinin hukukî niteliğini esas almaktadır. O bakımdan konkordato tasfiye memurlarının hukukî niteliğini ortaya koymadan önce konkordato komiseri ile iflâs idaresinin hukukî niteliği üzerinde kısaca durmakta fayda vardır. Konkordato komiserinin hukukî niteliği hakkında çeşitli görüşler ileri

\footnotetext{
${ }^{7}$ Öğretide malvarlığının terki suretiyle konkordatonun iflâstan nihai farkının borçlunun şerefli bir tacir olarak kalmaya devam etmesi, mal iktisabına, borç iltizamına tam yetkili olmayı sürdürmesi olduğu ifade edilmiştir. Bkz. Berkin, s. 204; Tevetoğlu, s. 934.

8 Tanrıver, s. 20; Tanrıver/Deynekli, s. 46. Karş. Buruloğlu/Reyna, s. 6. Bununla birlikte malvarlığının terki suretiyle konkordato bir iyileştirme tedbiri değildir. Zira malvarlığının terki suretiyle konkordato ile borçlunun malvarlığının tasfiyesi amacı güdülür. Bkz. Atalay, s. 104.

${ }^{9}$ Pekcanitez./Atalay/Sungurtekin Özkan,/Özekes, s. 639.

${ }_{11}^{10}$ Amonn/Walther, § 55 Nr. 28-29 (Ercan, s. 272'den naklen).

11 Winkelmann/Lévy/Jeanneret/Merkt/Birchler, s. 2871; Sprecher, T.: Der Gläubigerausschuss im schweizerischen Konkursverfahren und im Nachlassverfahren mit Vermögensabtretung, Zürich 2003, Nr. 916 (Ercan, s. 272'den naklen); Kuru, 1963, s. 140; Tercan, s. 125.
} 
sürülmüştür ${ }^{12}$. Hakim görüşe göre ${ }^{13}$ konkordato komiseri, devletin resmi bir organıdır. Bu görüş taraftarlarına göre konkordato komiserinin konkordato makamı tarafından atanmasını öngören işlem bir idari işlem niteliğindedir ve bu işlemin konusunu bir kamu görevinin bir kimseye bırakılması oluşturmaktadır. nitekim, yaptığı bütün işlemler, talep ve beyanlar hakkında düzenlediği tutanakların alenilik ve ispat gücü açısından, icra tutanakları ile eşdeğer konumda bulunması (m. 287, IV; m. 8), konkordatodaki alacaklar ve borçlunun malları hakkında kiminle olursa olsun, kendisi veya başkaları hesabına hukukî işlem yapamaması (m. 287, IV; m. 11), işlemlerine karşı şikâyet yoluna gidilebilmesi (m. 287, IV; m. 16) konkordato komiserinin devletin resmi bir organı olarak görev yaptığının delillerini teşkil etmektedir. Biz bu görüşe katılmakla birlikte konkordato komiserinin atanması işleminin idari değil yargısal bir işlem olduğu kanısındayız ${ }^{14}$. Zira konkordato komiseri de tıpkı icra ve iflâs müdürleri gibi hukuk kurallarını uygulamak suretiyle türü kendine özgü bir prosedür içerisinde ilgililerin haklarına kavuşmalarına yardımcı olmaktadır ${ }^{15}$. Burada sözü edilen normlar ise idare hukuku normları olmayıp; icra ve iflâs hukuku normlarıdır ${ }^{16}$. Bununla birlikte bu durum, yani komiserin atanması işleminin idari nitelikte değil yargısal (adli) nitelikte olması resmi organ görüşünün savunulmasına mani değildir. Konkordato komiserlerinin hukukî statü ve işlevleri açısından iflâs idaresinden ziyade icra ve iflâs memurlarına benzedikleri söylenebilir ${ }^{17}$.

Malvarlı̆̆ının terki suretiyle konkordato da ismine rağmen adi konkordatodan ziyade iflâsa yaklaşmaktadır. Zira kurumun temelindeki düşünce, borçlunun mali durumunu düzeltmek değil, mevcudunu en avantajlı şekilde paraya çevirerek alacaklıların alacaklarına kavuşmalarını sağlamaktır $^{18}$. İ̈K m. 309/c, IV, c. 1 uyarınca konkordato tasfiye memurları,

\footnotetext{
${ }^{12}$ Ayrıntılı bilgi için bkz. Tanrıver, S.: Konkordato Komiseri, Ankara 1993, s. vd.

${ }^{13}$ Papa, s. 48-49; Coradi, s. 85-87; Kuru, El Kitab1, s. 1255; Kuru, B.: İcra ve İflâs Hukuku, IV s. 3667; Postacioğlu, 1965, s. 68; Üstündağ, s. 209; Kuru/Arslan/Y1lmaz, s. 637. Bu görüş çeşitli yönlerden eleştirilmiştir. Bkz. Tanrıver, s. 121. Yazara göre konkordato komiseri, kamu görevi ifa eden bir kamu görevlisidir. Geniș bilgi için bkz. s. 124 vd. Kanımızca, bu iki görüşten hangisi kabul edilirse edilsin sonuçta konkordato komiserliği görevini ifa eden kişilerin kamu görevlisi sayılması vasfina halel gelmeyecektir.

${ }^{14}$ Karşı görüş hakkında detaylı bilgi için bkz. Pekcanıtez, s. 16 vd.

${ }^{15}$ Tanriver, s. 122.

${ }^{16}$ Tanriver, s. 122.

${ }^{17}$ Bkz. Tanriver, s. 130.

${ }^{18}$ Bkz. Hükümet Gerekçesi m. 85.
} 
mahkemelerde konkordato masasını temsil eder. Benzer bir hüküm iflâs idaresi için de mevcut olup İ̈K m. 226, I c. 1 uyarınca iflâs idaresi, iflâs masasının kanuni temsilcisidir. Bunun yanı sıra, hükümet gerekçesinde, konkordato tasfiye memurlarının durumunun, büyük ölçüde iflâs idaresinin durumuna benzediği; tasfiye memurlarının ise masanın kanuni temsilcisi olduğu ifade edilmiştir ${ }^{19}$. Nitekim, burada da borçlunun aktifleri bir masa oluşturmakta, tasfiye memurları bu aktifleri paraya çevirip, daha önce yine kural olarak iflâs tasfiyesi kuralları çerçevesinde tespit ettikleri alacaklılar arasında hazırladıkları sıra ve pay cetveline göre dağıtmaktadırlar. İflâs tasfiyesinde olduğu gibi malvarlığının terki suretiyle konkordato da konkordato masasının tüzel kişiliği yoktur. iflâs masasının kanuni temsilcisi iflâs idaresi iken (m. 226, I) konkordato masasının kanuni temsilcisi tasfiye memurlarıdır (m. 309/c, IV). İflâs idaresi gibi konkordato tasfiye memurlarının temsil yetkisi de doğrudan doğruya kanundan kaynaklanmaktadır ${ }^{20}$. Bütün bu hususlar dikkate alındığında konkordato tasfiye memurlarının hukukî niteliğinin belirlenmesinde konkordato komiserinden ziyade iflâs idaresinin hukukî niteliği hakkında ileri sürülen görüşlerden $^{21}$ yararlanılması gerektiği ortaya çıkmaktadır. Özellikle Alman hukuk öğretisinde hâkim görüş, iflâs idaresini kamu görevi yapan bir organ ${ }^{22}$ olarak nitelendirmektedir ${ }^{23}$. Bu görüşe göre, iflâs idaresi ne müflisin ne de iflâs alacaklılarının temsilcisidir; çünkü görevini müflisten veya alacaklılardan değil, doğrudan doğruya kanundan almaktadır. İflâs idaresi, masanın da kanuni temsilcisi değildir. Masa, iflâs idaresinin görev ve yetkisine verilmiş bir hukuk objesidir. İflâs idaresi, kamu yararı gereğince, devletin cebri icra gücünün kendisine devredildiği bir organdır. İflâs idaresine temsilci de denemez. Zira ortada temsil edilen bir kimse bulunmamaktadır. Kanun koyucu, iflâsı kamu düzeninden kabul etmiştir. Bu

\footnotetext{
${ }^{19}$ Bkz. Hükümet Gerekçesi m. 85 .

${ }^{20}$ Ercan, s. 273.

${ }^{21}$ Geniş bilgi için bkz. Y1lmaz, İflas İdaresi, s. 27 vd; Y1lmaz Sempozyum, s. 76 vd.

22 Organ kavramı, kanun maddeleri, tüzel kişinin statüsü, nizamnamesi veya iç talimatnameleriyle yetkili kılınan ve tüzel kişi için önemli olan korporatif görevleri devamlı ve bağımsız olarak gerek üçüncü şahıslarla olan ilişkilerinde, gerek tüzel kişinin iç teşkilatında, yerine getirmesi için yetkili kılınan veya kendisine bu tip görevleri fiilen dışa karşı belli olacak şekilde bağımsız ifa yetkisi verilen şahıs ve şahıs grupları olarak tanımlanabilir. Bkz. Öztan, s. 82.

${ }^{23}$ Bkz. Schoch, s. 82 dn. 34'deki literatür.
} 
nedenle, iflâs idaresi bir kamu görevi yapmaktadır ve bizatihi bir devlet organı olarak görülmelidir. Çünkü iflâs idaresinin resmi niteliği vardır ${ }^{24}$.

Kanımızca iflâs idaresini kamu görevi yapan bir organ olarak nitelendirmek güçtür. Zira bu görüşün sonucu olarak, iflâs idaresinin hiçbir kimseyi temsil etmeksizin kanun tarafindan verilen görevleri yaptığ belirtilmektedir. Ancak bu görüş doğru olsaydı, iflâs idaresinin takip ettiği davalardaki yargılama giderlerinin masaya yüklenmemesi gerekirdi. Oysa, iflâs idaresinin takip ettiği davalara ait giderler masa borcu sayılmaktadır. Öte yandan iflâs idaresi eğer sadece kamu yararına dava açsaydı, elde edilen ilamın müflis için kesin hüküm teşkil etmemesi gerekirdi. Oysa iflâs idaresinin açmış olduğu davada alınan hüküm, müflis ve onun halefleri için kesin hüküm teşkil etmektedir ${ }^{25}$. O halde iflâs idaresi büyük ölçüde ${ }^{26}$ kamu görevi ifa etmekle beraber onu devletin bir icra organı olarak görmek hatalıdır ${ }^{27}$. Bu düşünce konkordato tasfiye memurları bakımından da geçerli olmalidir.

Bu bilgiler dikkate alındığında konkordato tasfiye memurlarının AY m. 128, I uyarınca kamu görevlisi sayılıp sayılmayacakları üzerinde durmakta fayda vardır. Bahsi geçen hükme göre devletin, kamu iktisadi teşebbüsleri ve diğer kamu tüzelkişilerinin genel idare esaslarına göre yürütmekle yükümlü oldukları kamu hizmetlerinin gerektirdiği asli ve sürekli görevler, memurlar ve diğer kamu görevlileri ${ }^{28}$ eliyle görülür. Her şeyden önce belirtmek gerekir ki, tasfiye memurlarının görevi, adli hizmetlerin özel bir türünün ifasına yöneliktir. Adli hizmetler ise kamu hizmetleri arasında yer alır. Şu halde, tasfiye memuru da, tıpk1 konkordato tasfiye memuru gibi, kanunda öngörülen usul çerçevesinde hukuk normlarını uygulayarak, bireylerin hatta kamunun menfaatlerini adil ölçüler içerisinde uzlaştırmaya çalışmak suretiyle bir kamu hizmeti ifa etmektedir. Aslında bu görev, bizatihi devlet tarafindan yerine getirilmesi gereken bir görevdir. Tasfiye memuru, bu

${ }^{24}$ Y1lmaz, İflâs İdaresi, s. 37; Y1lmaz, Sempozyum, s. 84-85.

${ }^{25}$ Y1lmaz, İflâs İdaresi, s. 39; Y1lmaz, Sempozyum, s. 85.

${ }^{26}$ Karş. Yılmaz, İflâs İdaresi, s. 39; Yılmaz, Sempozyum, s. 85.

${ }^{27}$ Aksi görüşte: Deren-Yıldırım, s. 113. Yazara göre iflâs idaresi resmi karaktere sahiptir ve devletten kaynaklanan icra kuvvetini kullanan, kamu menfaatine hizmet eden bir organdir. Dolayısıyla sahip olduğu yetkiyi müflisten veya alacaklılardan değil; kanundan alan bağımsız bir organdır.

${ }^{28} \mathrm{Bu}$ deyimden ne anlaşılması gerektiği hakkındaki tartışmalar için özellikle bkz. Kanlıgöz, s. $190 \mathrm{vd}$. 
görevi, devlet adına yerine getirmektedir. Devletin bu görevi, yasal prosedür çerçevesinde görevlendirdiği kişi aracılığıyla yerine getirmesi görevin onun tarafindan ifa edilmediği anlamına gelmez. Fakat tasfiye memurunun kamu görevlisi sayılması için onun yapmış olduğu görevin toplumsal menfaate yönelik olması yeterli değildir. Ayrıca bu faaliyetin aslilik ve süreklilik niteliklerine de sahip olması gerekmektedir. Nitekim, Anayasa Mahkemesi vermiş olduğu 19.4.1988 tarihli kararında, Anayasa'nın 128 inci maddesinde geçen diğer kamu görevlileri ile memurlar ve işçiler dışında kamu hizmetinin gerektirdiği asli ve sürekli görevlerde yönetime kamu hukuku ilişkisiyle bağlı olarak çalışanların kastedildiğini açıklamıştır ${ }^{29}$. Tasfiye memurunun ifa etmiş olduğu görevin bu niteliklere de sahip olduğu söylenebilir. Zira bir kamu görevinin asliliğini ve sürekliliğini belirleyen olgu, onun süresi olmayıp; potansiyel olarak her an ilgililerin ihtiyaçlarına cevap verebilecek bir durumda bulunup bulunmadığıdır ${ }^{30}$. Tasfiye memurunun ifa etmiş olduğu görev de potansiyel olarak her an ilgililerin ihtiyaçlarını karşılayabilecek şekilde işler bir durumda tutulmaktadır. $\mathrm{Bu}$ bakımdan onun da kesintisiz ve sürekli olduğu söylenebilir. İlgililerin istemlerine göre zaman zaman işlerlik kazanması, komiserlik görevinin potansiyel olarak taşıdığı süreklilik ve kesintisizlik niteliğine aykırılık teşkil etmez $^{31}$. Zira asli ve sürekli olma niteliği çalışanın kişiliğine ve durumuna değil; yaptığı göreve bağlı bir koşuldur ${ }^{32}$.

İIKK m. 309/ç, II uyarınca 8, 9, 10, 11, 21 ve 359 uncu maddelerin tasfiye memurlarının işlemleri hakkında da kıyas yoluyla uygulanacağı kabul edilmiştir. $\mathrm{Bu}$ maddelerde icra ve iflâs memurlarının icra ve iflâs takibi süresince yapması gereken işlemler gösterilmiştir. Böylelikle tasfiye memurları, yaptıkları işlemlerde uymaları gereken kurallar bakımından icra ve iflâs memurlarına benzetilerek onların da resmi bir görevli oldukları dolaylı olarak ifade edilmiştir ${ }^{33}$. Nitekim, öğretide hâkim görüş tarafından ${ }^{34}$

${ }^{29}$ Bkz. RG. 23.8.1988, sa. 19908, s. 52.

${ }^{30}$ Balta, s. 21; Yayla, s. 65; Tanrıver, s. 132. Kamu hizmetlerinin kesintisiz yürütülmesi demek, onların mutlaka heran, günün ve gecenin her saatinde yürütülmesi gerektiği anlamına gelmez. Bu, giderilecek gereksinime göre değişir. Bkz. Günday, s. 298.

${ }^{31}$ Konkordato komiseri bakımından karş. Tanrıver, s. 132.

${ }^{32}$ Duran, s. 17.

${ }^{33}$ Jaeger/Walder/Kull/Kottmann, s. 189; Yücel/Kale, s. 521.

${ }^{34}$ Bkz. Haab, s. 150; Schoder, A.: Der Nachlassvertag mit Vermögensabtretung (ZBJV (88) 1952), s. 426-428; Böni. W.: Die Massenverbindlichkeiten im Nachlassvertrag mit 
konkordato tasfiye memurlarının özel hukuk anlamında vekil ya da kamu hukuku anlamında memur olmadıkları ${ }^{35}$; tıpk1 iflâs prosedüründeki konkordato komiseri, iflâs idaresi ve alacaklılar kurulu gibi kamu menfaatlerine ilişkin bir görev icra ettikleri savunulmuştur.

Kamu hizmeti, siyasal organlar tarafindan kamuya yararlı olarak kabul edilen, bir kamu kuruluşunun ya kendisi ya da yakın denetimi ve gözetimi altında özel kesim tarafından yürütülen faaliyetlerdir ${ }^{36}$. Devlet, mahalli idareler ve kamu kurumları tarafindan doğrudan doğruya yürütülen her faaliyetin sırf bu nedenle kamu hizmeti olduğu söylenemez. Bir faaliyetin kamu hizmeti olarak nitelendirilebilmesi için bu faaliyetin ayrıca, kamu yararı amacına yönelik olması ve özel hukuku aşan bir hukukî rejime tâbi olması da gerekmektedir ${ }^{37}$. Bu açıklamalar dikkate alındığında malvarlığının terki suretiyle konkordatonun da bu niteliklere sahip olduğu sonucuna varmak gerekir. Zira, tıpkı adi konkordatoda olduğu gibi malvarlığının terki suretiyle konkordatoda da korunması gereken menfaatler sadece borçlunun ve alacaklıların menfaatleri olmayıp; devlete, yani kamuya ait menfaatler de buraya dahildir. Diğer deyişle, korunması ve uzlaştırılması gereken menfaatlerin "kamu menfaatine dönüşmüş özel menfaatler" olduğu söylenebilir. Bireylere ait menfaatlerin korunması ve uzlaştırılması ile toplumsal menfaatlerin dengelenmesine ve düzenlenmesine ve bu suretle de kamu düzenin sağlanmasına hizmet eden konkordato tasfiye memurunun da, tıpkı konkordato komiseri gibi kamu yararı temeline dayalı bir görev yaptı̆̆ 1 söylenebiliir ${ }^{38}$. Bunun yanı sıra tasfiye memurunun malvarlığının paraya çevrilmesi işlemlerine karşı önce alacaklılar kuruluna itiraz imkânının tanınmış olması; kurulun bu konuda vermiş olduğu kararlara karşı da icra mahkemesi nezdinde şikâyet yolunun açık tutulmuş olması (İ̈K m. 309/ç, II); tasfiye memurunun diğer işlemlerine karşı ise doğrudan doğruya icra

Vermögensabtretung, Freiburg 1959, s. 60; Ludwig, s. 60. Brand, ise karşı görüştedir. Ona göre tasfiye memurları, kamu hukuku fonksiyonu icra etmezler. Onlar medeni hukuk anlamında vekildirler. Bkz. Brand, E.: Juristische Kartothek, Karten Nr. 1034, s.12 (Ludwig, s. 60 dn. 48'den naklen).

${ }^{35}$ Gerçekten tasfiye memuru ne anayasa ne de idare hukuku anlamında memur sayılır. Zira o, kamu hizmetinin gerektirdiği asli ve sürekli bir görevi yerine getirmekle beraber, hiçbir zaman idarenin daimi ve sabit kadrosunu işgal etmemekte; idarenin hiyerarşik yapısı içerisinde yer almamaktadır. Konkordato komiseri bakımından bkz. Tanrıver, s. 135.

${ }^{36}$ Günday, s. 298.

${ }^{37}$ Gözler, s. 424.

${ }^{38}$ Konkordato komiseri bakımından bkz. Tanrıver, s. 124. 
mahkemesinde şikâyet yoluna başvurulabileceğinin kabul edilmesi ${ }^{39}$ tasfiye memurunun vermiş olduğu kararların nihai olarak mahkemenin denetimine tâbi tutulması, kanımızca, onun ifa etmiş olduğu görevin kamuyu yakından ilgilendirmesinin doğal bir sonucudur.

Konkordato tasfiye memuru alacaklılar tarafindan seçilmekle birlikte burada da kanun koyucu, onun göreve başlamasını icra mahkemesinin seçime ilişkin kararı onaylamasına bağlı kılmış (İ̈K m. 309/a, II c. 3); bu konuda alacaklılara tam bir özgürlük tanımamıştır. Kanımızca bu düzenlememin altında yatan düşünce de malvarlı̆̆ının terki suretiyle konkordatoda alacaklıların yanı sıra, borçlunun ve kamunun menfaatlerinin de göz önünde tutulmasından, diğer bir deyişle tasfiye memurlarının kamu görevi görmelerinden kaynaklanmaktadır.

Keza tasfiye memurunun görevlendirilmesi, bir özel hukuk sözleşmesiyle değil, tıpkı konkordato komiserinkinde olduğu gibi kamusal nitelik taşıyan resmi bir işlemle gerçekleştirilmekte ve kendisi de icra ve iflâs hukuku normları çerçevesinde konkordato içerisinde faaliyet gösterdiğine göre, ücretinin tutarının belirlenmesinde özel hukuka ait düzenlemelerin değil de kamu hukuku bütünü içerisinde yer alan düzenlemelerin esas alınması daha doğru olacaktır ${ }^{40}$.

Tasfiye memurlarının ücret alacaklarının nasıl belirleneceği konusunda ne İcra ve İflâs Kanunu'nda ne de İcra ve İflâs Kanunu Yönetmeliği'nde herhangi bir düzenleme yer almaktadır. Öğretide ${ }^{41}$ bu konuda en uygun yolun ücretin malvarlığının terki suretiyle konkordatoda belirlenmesi olduğu ifade edilmiştir. Belirlenecek ücretin miktarı, tasdik makamı olan ticaret mahkemesinin onayına tâbidir. Ticaret mahkemesi bu konuda gerekli gördüğü değişikliği yapma yetkisine sahiptir ${ }^{42}$. Bu görüşten de anlaşılacağ 1 üzere tasfiye memurunun ücretinin belirlenmesi konusunda borçlu ve alacaklılara tam bir özgürlük tanınmamış; bu konuda mahkemenin gerekli değişikliği yapabileceği ifade edilmiştir. Kanımızca, bu husus da, tasfiye memurunun yaptığı işin bir kamu görevi, kendisinin de bir kamu görevlisi sayılması gerektiği yönünde bir delil olarak kabul edilebilir. Tasfiye

\footnotetext{
${ }^{39}$ Ercan, s. 293.

${ }^{40}$ Konkordato komiseri bakımından bkz. Tanrıver, s. 142.

${ }^{41}$ Ercan, s. 284.

42 Ercan, s. 284.
} 
memurlarının ücretlerini devletten almıyor olmalarının onların birer kamu görevlisi sayılmalarına engel olmayacağı kanısındayız. Nitekim, Anayasa Mahkemesi de yeminli mali müşavirlerle ilgili olarak vermiş olduğu 19.03.1987 tarihli bir kararında onların memurlar gibi devletten maaş almamalarına rağmen kullandıkları tasdik yetkisi dikkate alındığında bir kamu yetkisi kullandıkları ve yaptıkları hizmetin de bir kamu hizmeti olduğu; devlet ile aralarındaki ilişkinin kamu hukuku ilişkisi olduğunu belirtmiş ve onların birer kamu görevlisi sayılmaları gerektiği sonucuna varmıştır $^{43}$. Görüldüğü gibi yüksek mahkemeye göre de bir kimsenin maaşını devletten ya da bir kamu kurumundan almıyor oluşu onun kamu görevlisi sayılmasına bir engel değildir.

Tasfiye memurlarının istifa hakkına sahip olduğu kabul edilmektedir. Fakat tasfiye memurlarının görevlerinden istifa etmelerinin tasfiyeyi kesintiye uğratmaması gerektiği; bu nedenle gerekirse yerlerine yenileri göreve başlanıcıya kadar görevlerine devam etmeleri gerektiği, aksi takdirde hukukî ve cezaî yönden sorumlu duruma düşebilecekleri kabul edilmektedir ${ }^{44}$. Bu husus da, kanımızca, onların birer kamu görevlisi olmasıyla açıklanabilir.

Öğretide ${ }^{45}$ tasfiye memurları üzerinde icra mahkemesinin disiplin yetkisi olduğu kabul edilmektedir. Kanımızca, bu da onların kamu görevlisi sayılmaları konusunda bir delil olarak ileri sürülebilecektir.

Özetle, tasfiye memuru geçici, ücretli ve ihtiyari olarak bir kamu hizmeti gören kamu görevlisidir ${ }^{46}$.

\section{SEÇIMI}

İ̈K Yön. m. 107'de konkordato tasfiye memurlarının konkordato hakkında karar veren alacaklılar, alacaklılar temsilcileri veya üçüncü kişiler arasından üç kişiyi geçmemek üzere seçileceği ve konkordato komiserinin de tasfiye memuru seçilebileceği hükme bağlanmıştır. İsviçre hukukunda borçlunun konkordato tasfiye memuru olarak seçilip seçilemeyeceği

\footnotetext{
${ }^{43}$ Bkz. RG 12.11.1987, sa.19632, s. 43.

${ }^{44}$ Ercan, s. 284. Konkordato komiseri bakımından bkz. Tanrıver, s. 147.

${ }^{45}$ Ercan, s. 291.

46 İflâs idaresi memurları bakımından karş. Erman, S.: İflâs İdaresi Memurları Ceza Kanunu'nun Tatbikinde Memurdurlar (Ï̈̈HFM 1975/3-4), s. 39; Umar, s. 267.
} 
tartışmalıdır. Bir görüşe göre ${ }^{47}$ borçlunun da tasfiye memuru seçilmesi mümkündür. Buna karşılık, bizim de katıldığımız, hâkim görüş ${ }^{48}$, borçlunun tasfiye memur olması durumunda görevini yeterince objektif olarak yerine getiremeyeceği ve alacaklıların zararına hareket etmesinin mümkün olduğu gerekçesiyle buna karşı çıkmaktadır. Bu görüşün temsilcilerinden biri olan Ludwig'e göre ${ }^{49}$ borçlunun tasfiye memuru seçilmesinin üçüncü kişiler üzerinde yanıltıcı etkisi olabilecektir. Tasfiye memurunun bağımsızlı̆̆ ve icra ettiği görevin kamu menfaatini ilgilendirmesi nedeniyle borçlunun tasfiye memuru seçilmesi uygun olmayacaktır. Kuru ${ }^{50}$ ise konkordatonun tasdikiyle borçlunun konkordato konusu mallar üzerinde tasarruf yetkisini kaybetmiş olması ve borçlunun menfaatiyle alacaklıların menfaatinin çatışma halinde bulunması nedeniyle borçlunun tasfiye memuru seçilemeyeceğini ileri sürmüştür. Bunun yanı sıra az önce değinilen 107 inci maddenin birinci fikrasında borçluya konkordato tasfiye memuru seçilecek kişiler arasında yer verilmediği göze çarpmaktadır. Bu bakımdan kanımızca Türk hukuku bakımından borçlunun, tasfiye memuru seçilemeyeceği sonucuna ulaşmak mümkündür. Yönetmelikte, alacaklıların da tasfiye memuru olarak atanabilecekleri öngörülmüşse de, öğretide, kendisinin de tasfiyenin tarafi olması nedeniyle diğer alacaklılara karşı yeteri kadar objektif olamayabileceği endişesiyle, uygulamada bir veya birden fazla alacaklının tasfiye memuru olmasına diğer alacaklıların soğuk bakacakları dile getirilmiştir ${ }^{51}$.

Öğretide ${ }^{52}$ haklı olarak, tasfiye memurlarının, konkordato hakkında gerekli bilgi ve tecrübeye sahip kimseler arasından seçilmesi gerektiği ifade edilmiştir. bu bağlamda, sahip oldukları hukuk ve ekonomi bilgisi dikkate alındığında avukatların seçilmesi uygun olabiliir ${ }^{53}$. Tasfiye memurlarının seçimine karşı icra mahkemesi nezdinde şikâyet yoluna başvurulabilir ${ }^{54}$.

${ }^{47}$ Schwyzer, A.: Der gerichtliche bestätigte Nachlassvertrag mit Vermögensabtretung ausser Konkurs, insbesondere nach schweizerischem Recht, Bonn 1939, s. 106 (Ercan, s. 268'den naklen).

${ }^{48}$ Ludwig, s. 52; Coradi, s. 56; Ercan, s. 268-269.

${ }^{49}$ Ludwig, s. 52.

${ }^{50}$ Kuru, IV, s. 279.

${ }^{51}$ Jaeger/Walder/Kull/Kottmann, s. 171.

52 Jaeger/Walder/Kull/Kottmann, s. 171; Yücel/Kale, s. 521.

${ }^{53}$ Winkelmann/Lévy/Jeanneret/Merkt/Birchler, s. 2872.

${ }^{54}$ Winkelmann/Lévy/Jeanneret/Merkt/Birchler, s. 2872. 
Tasfiye memurlarının gerçek kişi olmaları şart olmayıp; tüzel kişiler de tasfiye memuru seçilebilir ${ }^{55}$.

İsviçre hukuk öğretisinde tasfiye memurlarının seçiminde iflâs memurlarından da yararlanılabileceği; zira bu kişilerin sıra ve pay cetvelinin hazırlanması, rehinli ve imtiyazlı alacaklılar hakkında yapılacak işlemler bakımından iyi derecede bilgi sahibi oldukları dile getirilmiştir ${ }^{56}$.

Konkordatoyu tasdik edecek ticaret mahkemesi konkordato tasfiye memurlarını bizzat seçemez. Hatta alacaklıların bu konuda konkordato projesinde rızalarını belirtmiş olmaları durumunda dahi durum değişmez. Zira burada, yetersiz olan bir konkordatonun tamamlanması değil; kanun tarafından alacaklılar toplanmasına tanınmış bir yetkinin kullanımı söz konusudur ${ }^{57}$.

Seçilecek tasfiye memurlarının sayısı tasfiyesi söz konusu olan işletmenin büyüklügüne göre değişecektir. Daha sonra yeniden tasfiye memuru seçiminden kaçınmak için daha baştan temsilci atanması ya da alacaklılar kuruluna konkordatoda tasfiye memurlarından sonradan doğacak boşluğu doldurma konusunda yetki verilmesi isabetli olacaktır ${ }^{58}$. Bunun yanı sıra konkordatoda tasfiye memurlarının değişken bir sayı olarak belirlenmesi de mümkündür. Örneğin bir ilâ üç tasfiye memuru gibi ${ }^{59}$. İiKK m. 309/b/2 (İsv. İIK m. 318, I/2) uyarınca, konkordato tasfiye memurları ile alacaklılar kurulu üyelerinin belirlenmesi ve bunların yetkilerinin ne olduğunun konkordatoda yer alması zorunlu tutulmuştur. İcra ve İflâs Kanunu Yönetmeliği'nin 107 nci maddesinin birinci fikrasında ise tasfiye memurları sayısının üç kişiyi geçmemesi gerektiği öngörülmüştür. $O$ halde tasfiye memurlarının sayısı bir ilâ üç arasında değișecektir. Gersbach ${ }^{60}$, sayının konkordatoda belirlenmesine ilişkin hükmü tasfiye sırasında ihtiyaçların değişebileceği gerekçesiyle haklı olarak eleştirmiştir. Nitekim, bu düşünce dikkate alınarak, tasfiye memurunun veya memurlarından birinin görevinin

${ }^{55}$ Coradi, s. 56; Schoder, s. 427; Amonn, K./Gasser, D.: Grundriss des Schuldbetreibungsund Konkursrechts, Bern 1997, s. 359; Winkelmann/Lévy/Jeanneret/Merkt/Birchler, s. 2871; Yücel/Kale, s. 521.

${ }^{56}$ Ludwig, s. 52.

${ }^{57}$ Ludwig, s. 49-50; Tschan, s. 38; Haberthür, s. 75.

${ }^{58}$ Glarner, s. 32.

${ }^{59}$ Ludwig, s. 53.

${ }^{60}$ Gersbach, s. 157. 
herhangi bir sebepten dolayı sona ermesi halinde, yerine seçilecek kişide sorun yaşanmaması için, yedek kişilerin üye seçilmesi veya konkordato ile bu konuda alacaklılar kuruluna yetki verilmesinin uygun olacağı ifade edilmiştir ${ }^{61}$.

Konkordatoda belirtilmesi durumunda alacaklılar toplantısında ayrica yedek tasfiye memurlarının da seçilebileceği kabul edilmektedir ${ }^{62}$.

\section{GÖREV VE YETKİLERİ}

İ̈K m. 309/c, III uyarınca konkordato tasfiye memurları, konkordato masasının muhafazası ve paraya çevrilmesi veya lüzumu halinde malların devri için gerekli bütün işlemleri yerine getirir. Konkordato tasfiye memurları ayn 1 zamanda mahkemelerde konkordato masasını temsil eder ( $\mathrm{m}$. 309/c, IV, c. 1; İsv. İ̈K m. 319, IV, c. 1). Bu iki hükümden de anlaşılacağı üzere idareye ve paraya çevirmeye ilişkin tüm görevler, tasfiye memurlarına havale edilmek zorundadır ve dişarıya karşı temsil, onların görevidir. Alacaklılar kuruluna ise gözetim ve denetim görevi düşmektedir. $\mathrm{Bu}$ hükümler emredici olup; konkordato ile değiștirilemez. Alacaklılar kurulu, icrai bir organ olmadığından ve alacaklıları dışarıya karşı temsil etmediğinden $^{63}$ aktiflerin paraya çevrilmesi işini kendi üzerine alamaz ${ }^{64}$. Fakat o, paraya çevrilmeye ilişkin olarak tavsiyede bulunabilir; gerekirse talimat verebilirr ${ }^{65}$.

İ̈K m. 309/c, IV, c. 2 uyarınca 228. madde kıyas yoluyla uygulanır. Bu maddeye göre, üçüncü şahısların istihkak iddiasında bulunması halinde, bu istihkaka konu olan malın üçüncü kişiye verilip verilmeyeceğini iflâs idaresi kararlaştırır. İflâs idaresi, istihkak iddialarını reddederse, üçüncü şahsa icra mahkemesinde istihkak davası açması için yedi günlük bir mühlet tayin ve tebliğ eder. Aktifin terki suretiyle konkordatoda iflâs idaresinin bu görevlerini tasfiye memurları yerine getirir ${ }^{66}$.

\footnotetext{
${ }^{61}$ Ercan, s. 270.

${ }^{62}$ Winkelmann/Lévy/Jeanneret/Merkt/Birchler, s. 2880; Yücel/Kale, s. 521.

${ }^{63}$ Erdönmez, s. 204; Ercan, s. 280.

${ }^{64}$ Giovanoli, s. 108; Ludwig, s. 53.

${ }^{65}$ Giovanoli, s. 108.

${ }^{66}$ Yücel/Kale, s. 522
} 
Tasfiye memurlarının görevi, icra mahkemesinin memurların seçimine ilişkin kararı onaylamasından, tasfiyenin sona erip nihai raporun hazırlanmasına kadar devam eder (İIK m. 309/j, I).

Tasfiye memurlarının başlıca görevleri şu şekilde sıralanabilir ${ }^{67}$ : Paylaştırmaya katılacak alacaklıları ve sıralarını belirlemek (IIIK m. 309/d, I); konkordato masasını oluşturan malvarlığını paraya çevirmek (İ̈K m. 309/e); borçlunun ihtilaflı veya tahsili güç bir alacağını herhangi bir alacaklıya devredilmesi konusunda alacaklılar kuruluna teklifte bulunmak (İIK m. 309/̆̆g, I); geçici de olsa her dağıtımdan önce pay cetveli düzenleyip $^{68}$; payın miktarını alacaklılara bildirmek ve alacaklıların görmesi için iflâs dairesinde incelemeye hazır bulundurmak (İ̈K m. 309/h), tasfiye bitince bir nihai rapor hazırlayarak alacaklılar kurulunun onayına sunmak, tasfiyenin bir yıldan uzun sürmesi halinde, malvarlığının durumunu gösteren bir cetvel ve faaliyet raporu hazırlayarak alacaklılar kuruluna sunmak (IїK m. 309/j).

İIK m. 309/ç, III'de, İIKK m. 223'e atıf yapılmamıştır. Bundan hareketle konkordato tasfiye memurlarının, sulh olmak, tahkim sözleşmesi yapmak, davaları takip etmek, borçlunun işletmesini işletmek ya da tasfiye sürecinde geçici dağıtımda bulunmak gibi hususlarda alacaklılar kurulundan yetki almak zorunda olmadı̆̆ sonucuna varılabilir ${ }^{69}$. Alacaklılar kurulu, bahsi geçen konularda sadece tavsiye niteliğinde karar verebilir. Bununla birlikte İsviçre hukuk uygulamasında konkordato tasfiye memurlarının tasfiye sonucunu önemli derecede etkileyecek konularda alacaklilar kurulunun görüşünü almayı tercih ettikleri gözlemlenmiştir ${ }^{70}$.

\footnotetext{
${ }^{67}$ Yücel/Kale, s. 522-523. Karş. Ercan, s. 276-278.

${ }^{68}$ Borçlunun bütün malvarlığının paraya çevrilmesi uzunca bir zaman sürebilir. Bu sebeple, paraların paylaştırılması için, tasfiyenin sonuna kadar beklemek doğru olmayacaktır. Onun için, konkordato tasfiye memurlarına masa mallarını tasfiye edildikçe geçici dağıtımlarda bulunma yetkisi tanınmıştır. Bütün masa malları tasfiye edilince de kesin dağıtım yapılır. Konkordato tasfiye memurları her geçici dağıtımdan önce geçici bir pay cetveli düzenlemek, bunu alacaklılara bildirmek ve alacaklıların görmesi için on gün müddetle iflâs dairesinde incelemeye hazır bulundurmakla yükümlüdürler. $\mathrm{Bu}$ on günlük müddet içinde, alacaklılar pay cetveline karşı icra mahkemesine şikâyette bulunabilirler. Paylaştırma için pay cetvelinin kesinleşmesi gerekir (İ̈K m. 85'e ilişkin hükümet gerekçesi).

${ }^{69}$ Winkelmann/Lévy/Jeanneret/Merkt/Birchler, s. 2904.

${ }^{70}$ Winkelmann/Lévy/Jeanneret/Merkt/Birchler, s. 2904-2905.
} 
Paraya çevirmenin usulü ve zamanı tasfiye memurlarının getirecekleri öneri üzerine alacaklılar kurulu tarafından belirlenecektir (İIK m. 309e, II) ${ }^{71}$. Tasfiye memurları, konkordatonun tasdiki kararı kesinleştikten sonra konkordato masasındaki mal ve hakların özelliklerini ve mevcut piyasa koşullarını göz önünde tutarak alacaklılar kuruluna paraya çevirmenin hangi usulde ve ne zaman yapılacağına dair bir öneri sunacaklar, alacaklılar kurulu da bu öneriyi değerlendirerek karar verecektir ${ }^{72}$. Kanun koyucunun paraya çevirmenin usulü ve zamanını belirleme yetkisini doğrudan doğruya alacaklılar kuruluna bırakmaması öğretide ${ }^{73}$ olumlu karşılanmıştır. Tasfiye memurlarının konkordato masasına giren malların muhafazası ve satışıyla ilgili işlemleri yerine getirmekle yükümlü oldukları, bu sayede masadaki malların nitelikleri ile mevcut piyasa koşulları hakkında alacaklılar kuruluna göre daha fazla bilgi sahibi olabilecekleri ve bunun doğal bir sonucu olarak da paraya çevirmenin zamanı ve usulü hakkında masanın menfaatine daha uygun öneriler getirebilecekleri buna gerekçe gösterilmiştir. Bununla birlikte bu düzenlemenin ne derece mutlak olduğu, diğer deyişle alacaklılar kurulunun tasfiye memurlarından herhangi bir öneri gelmediği tüm hallerde paraya çevirmenin zamanı ve usulü hakkında hakkında karar verip veremeyecekleri sorusu ortaya atılmıştır. İIKK m. 309e, II'nin lafzı dikkate alındığında alacaklılar kuruluna böyle bir yetkinin tanınmadığı söylenebilir. Buna karşılık, öğretide ${ }^{74}$, kanunun lafzına sıkı sıkıya bağlı kalınması ve alacaklılar kurulunun hiçbir durumda doğrudan doğruya karar veremeyeceğinin kabul edilmesi durumunda konkordato masasının bundan zarar görebileceğine dikkat çekilmiş ve satılması güç olan bir mala iyi bir alıcı çıkmışsa veya bir mal hızla değer kaybettiği için hemen satılmasının gerekmesi durumunda, tasfiye memurlarının öneri sunmalarının beklenmemesi gerektiği; aksi halde masanın zarara uğrayabileceği ifade edilmiş; bunun sonucu olarak da alacaklılar kurulunun acele hallerde tasfiye memurlarından herhangi bir öneri gelmesini beklemeden paraya çevirmenin

71 İsviçre İIK' da ise tasfiye memurları, paraya çevirmenin zamanı ve usulünü alacaklılar kurulunun muvafakatıyla belirleyecekleri öngörülmüştür (m. 322, I). Dolayısıyla, İsviçre hukukunda tasfiye memurlarına paraya çevirmenin zamanı ve usulünün belirlenmesi hususunda Türk hukukuna göre daha etkin bir konumda bulundukları söylenebilir. Bkz. Erdönmez, s. 205 dn. 36.

72 Erdönmez, s. 205.

${ }^{73}$ Erdönmez, s. 205.

${ }^{74}$ Erdönmez, s. 206. 
zamanı ve usulünü kararlaştırabileceği sonucuna varılmıştır. Kanımızca da bu görüsşe hak vermek gerekir. Daha önce de ifade edildiği gibi malvarlığının terki suretiyle konkordato esas olarak adi konkordatodan ziyade iflâsa yaklaşan bir kurumdur. İflâsta da birinci alacaklılar toplanmasının, bazı malların (m. 229, II) pazarlıkla satılması hakkında acele karar verebileceği kabul edilmiştir (m. 224, I). Öğretide ${ }^{75}$ ise bir adım daha ileri gidilerek, masanın menfaatinin bulunduğu hallerde, alacaklıların, bazı malların şimdiden (hatta pazarlıkla) satılmasına, birinci alacaklılar toplantısında dahi karar verilebilmesi gerektiğine işaret edilmiştir. Şu halde masanın menfaatlerinin korunması gereken acele hallerde alacaklılar kurulunun tasfiye memurlarından gelecek teklifi beklemeksizin paraya çevirmenin şekli ve zamanı hakkında karar verebilmeleri gerekir. Bununla birlikte, alacaklılar kurulunun kararının kanuna aykırı olduğuna veya hadisenin özelliklerine uygun düşmediğini düşünen alacaklılar, bu karara karşı icra mahkemesi nezdinde şikâyet yoluna başvurabileceklerdir ${ }^{76}$.

Paraya çevirmenin usulü ve zamanı alacaklılar kurulu tarafından belirlendikten sonra, satış işlemleri bu karara uygun olarak tasfiye memurları tarafından gerçekleştirilir (İIK m. 309/c) Tasfiye memurları, alacaklılar kurulunun vermiş olduğu kararın gereklerini yetire getirmezlerse, kurul, bir hakkın yerine getirilmediği iddiasıyla icra mahkemesi nezdinde şikâyet yoluna başvurabilir ${ }^{77}$.

Malvarlığının terki suretiyle konkordatoda tasfiye memurları tasfiyenin bir yıldan fazla sürmesi halinde tasfiye edilen malvarlığının ve henüz paraya çevrilmemiş malların durumunu gösteren bir cetvel ile faaliyetleri hakkındaki raporu en geç Aralık ayı sonuna kadar alacaklılar kuruluna sunar (İK m. 309j, II). Tasfiye memurlarının hazırladıkları bu raporun çok kapsamlı olmasına gerek yoktur. Rapor, tasfiye memurlarının konkordatonun tasdik edildiği tarihten bu yana yaptıkları önemli işlemler hakkında bilgi içermeli; ayrıca raporu inceleyenler nihai raporun muhtemelen ne zaman düzenleneceği ve tasfiye sonunda kendilerine tahminen ne kadar pay dağıtılacağı hususunda bilgi sahibi olabilmelidirler. Tasfiye memurları alacakl1lar kuruluna daha önce ara rapor vermişlerse, yeni sunulacak ara

\footnotetext{
${ }^{75}$ Kuru, El Kitab1, s. 1100.

${ }^{76}$ Erdönmez, s. 206.

${ }^{77}$ Giovanoli, s. 108; Ludwig, s. 53; Sprecher, s. 291 (Erdönmez, s. 208'den naklen).
} 
rapor önceki raporun verildiği tarihten sonra yapılan işlemleri kapsayacaktır $^{78}$. Tasfiye memurları kanuni yükümlülüklerini yerine getirmemiş ve bahsi geçen cetvel ile ara raporu hiç düzenlememişlerse, alacaklılar, tasfiye memurlarının bir hakkı yerine getirmekten kaçındıkları gerekçesiyle icra mahkemesi nezdinde herhangi bir süreye tâbi olmaksızın şikâyet yoluna başvurabilirler (İ̈K m. 16, II) ${ }^{79}$. Alacaklılar kurulu yaptı̆̆ 1 inceleme sonucunda ara raporda eksiklikler tespit ederse, raporu geri çevirerek tasfiye memurlarından bu eksikliklerin giderilmesini isteyebilir. Raporda bir eksiklik yoksa alacaklılar kurulu, cetvel ve ara raporu takip eden yılın Şubat ayı sonuna kadar alacaklıların incelemesine hazır bulundurulmak üzere konkordatoyu tasdik edecek makama sunar (İIK m. 309j, II, c. 2). Tasfiye memurları, her yıl düzenledikleri ara raporlar yanında tasfiyenin bitiminde bir nihai rapor düzenleyecek ve bu raporu alacakl1lar kurulunun onayına sunacaklardır (İ̈K m. 309j, I). Nihai rapor, daha önce düzenlenen ara raporlar, sira cetveli, mükellefiyetler listesi, kesin pay cetveli, son hesap, tasfiye sırasında takip edilen davalar ve akdedilen sulh sözleşmeleri ile tasfiye sırasında takip edilen davalar ve akdedilen sulh sözleşmeleri ile tasfiye memurları ve alacaklılar kurulunun tasfiye sırasında ortaya çıkan sorunlar hakkında verdiği kararlar hakkında bilgi içermelidir. Zira alacaklılar, icra mahkemesi ve konkordatoyu tasdik edecek olan ticaret mahkemesi, tasfiyenin ne ölçüde kanuna uygun biçimde gerçekleştirildiğini nihai raporu inceleyerek tespit edebileceklerdir ${ }^{80}$.

Tasfiye memurları, tasfiyenin bitiminde nihai rapor düzenlemedikleri takdirde, alacaklıların buna karşı hukukî çareye başvuracakları tartışmalıdır. Bazı yazarlar ${ }^{81}$, bu durumda, alacaklıların alacaklılar kurulu nezdinde itiraz yoluna başvurabileceklerin savunmakta iseler de (İ̈K m. 309ç, I) bu görüşe, Kanun'da itiraz yoluna tasfiye memurlarının paraya çevirmeye ilişkin kararlarına karşı gidilebileceği (İ̈K m. 309ç, I); nihai raporun düzenlenmesinin ise bir paraya çevirme işlemi olmadığı gerekçesiyle karşı çıkılmış ve bu durumda alacaklıların ellerindeki tek imkânın bir hakkın

\footnotetext{
${ }^{78}$ Winkelmann/Lévy/Jeanneret/Merkt, s. 2957.

${ }^{79}$ Erdönmez, s. 216.

80 Jaeger/Walder/Kull/Kottmann， s. 229; Winkelmann/Lévy/Jeanneret/Merkt， S. 2960; Erdönmez, s. 217.

${ }^{81}$ Winkelmann/Lévy/Jeanneret/Merkt, s. 2960.
} 
yerine getirilmediği gerekçesiyle icra mahkemesi nezdinde şikâyet yoluna başvurmaktan ibaret olduğu ifade edilmiştir (İ̈K m. 16, II) ${ }^{82}$.

İ̇K m. 309/i, I'de "konkordato tasfiye memurları tarafindan belirlenen sürede hak sahipleri tarafından tahsil edilmeyen paylar..." dan bahsedildiğine göre payların tahsil edilmesi için gerekli süreyi belirlemek de tasfiye memurlarının görevleri arasındadır.

\section{YÜKÜMLÜLÜKLERİ}

Tasfiye memurlarının yukarıda sayılan görevleri yerine getirirken İIK'nın 8,9, 10, 11, 21 ve 359 uncu maddelerine uymaları gerektiği ayrıca hükme bağlanmıştır (IİK m. 309/ç, III). Bahsi geçen hükümler dikkate alındığında tasfiye memurlarının yükümlülükleri şu şekilde sıralanabilir ${ }^{83}$ :

1. İcra ve iflâs memurları gibi tasfiye memurları da yaptıkları işlemlerde, kendilerine vaki talep ve beyanların hakkında bir tutanak düzenlemek (İ̈K m. 8).

2. Para, kıymetli evrak ve değerli eşyaları bankaya yatırmak veya kasada muhafazaya etmek (İIK m. 9).

3. İcra ve iflâs memurları gibi, tasfiye memurları da iş görmekten memnu oldukları kimselerin işlemlerini görmekten kaçınmalıdırlar (İ̈K m. 10).

4. Tasfiye memurları, tasfiye konusu olan bir alacak veya satılmakta bulunan bir şey hakkında kiminle olursa olsun kendileri veya başkaları hesaplarına bir akit yapamazlar (İK m. 11).

5. Tasfiye memurları, yaptıkları işlemlerden dolayı her daire ve makam ile doğrudan doğruya muhabere edebilirler (İ̈K m. 359).

Yukarıda Kanununda açıkça düzenlenen yükümlülüklerin yanı sıra tasfiye memurlarının tasfiye dolayısıyla öğrendikleri borçluya ait sırları saklamak ve yüklenmiş oldukları görevi bizzat yerine getirmek gibi yükümlülüklerinin de olduğu kabul edilmektedir ${ }^{84}$.

\footnotetext{
${ }^{82}$ Sprecher, s. 303 (Erdönmez, s. 217'den naklen).

${ }^{83}$ Yücel/Kale, s. 523; Ercan, s. 284-286. Karş. Jaeger/Walder/Kull/Kottmann,, s. 190.

${ }^{84}$ Ercan, s. 285. İflâs idaresi memurları bakımından karş. Yılmaz, s. 91 vd. Konkordato komiseri bakımından karş. Tanrıver, s. 154 vd.
} 
Malvarlığını kısmen veya tamamen üçüncü kişiye devrinde, tasfiye gerçekleşmeyecek, tasfiye memurlarının görevi sadece bu malların mülkiyetinin üçüncü kişilere devredilmesi için gerekli işlemlerin yapılması ${ }^{85}$ ve sonucunda elde edilen paranın alacaklılara dağıtılması ile sınırlı olacaktır ${ }^{86}$.

\section{HAKLARI}

Tasfiye memurlarının hakları denince akla öncelikle ücret alacağı ve istifa hakkı gelir. Tasfiye memurlarının ücret alacağı hakkında tıpkı konkordato komiserlerinkinde olduğu gibi mevzuatta herhangi bir düzenlemeye yer verilmemiştir. Bununla birlikte bu durum, şüphesiz onların ücret alacaklarının olmadığı anlamına gelmez. Onlar da tıpkı iflas idaresi üyeleri ve konkordato komiseri gibi yapmış oldukları işlerin karşılığı olarak bir ücret alırlar.

Konkordato komiserinin ücreti hakkında, onların görevlendirilmesinin bir özel hukuk sözleşmesiyle değil de kamusal nitelik taşıyan resmî bir işlemle gerçekleştirildiğine ve kendisinin de icra ve iflâs hukuku normları çerçevesinde konkordato içerisinde faaliyet gösterdiğinden bahisle ücretlerinin tutarının belirlenmesinde özel hukuka ait düzenlemelerin değil de; kamu hukuku bütünü içinde yer alan düzenlemelerin esas alınması gerektiği ifade edilmiştir ${ }^{87}$. Olması gereken hukuk bakımından, konkordato borçlusunun aktiflerinin tutarının belirli bir yüzdesinin esas alınması suretiyle, komiserlik ücretinin belirlenmesini öngören ve bu yapılırken işin nitelik ve özelliklerinin, sarf edilen emek ve mesainin, ayrıca avukat, noter gibi nitelikli kimselerin komiser olarak atanması halinde, bunların mensup oldukları meslek kuruluşları için geçerlilik taşıyan ücret tarifelerinin de dikkate alınmasına izin veren bir Komiserlik Ücreti ve Masrafları Tarifesinin çıkartılması önerilmiş; mevcut düzenleme karşısında ise komiserlik ücretini belirleme yetkisine sahip olan icra mahkemesinin bu belirlemeyi yaparken Iflâs İdaresi Ücreti, Yazı ve Tebliği Masrafi Tarifesi ${ }^{88}$ hükümlerinden yararlanılabileceği dile getirilmiştirr ${ }^{89}$.

85 Taşınmazlar için tapu kütüğünde tescil işlemlerinin, taşınırlar için zilyetliğin devri ve teslimin yapılması gerekir.

${ }^{86}$ Jaeger/Walder/Kull/Kotmann, s. 188; Hunkeler, s. 300 (Yücel/Kale, s. 524'den naklen).

${ }^{87}$ Tanriver, s. 142.

${ }^{88}$ Bkz. RG 11.7.2007, sa. 26579.

${ }^{89}$ Tanriver, s. 142. 
Benzer şeyler, konkordato tasfiye memurunun ücret alacağının tespiti hakkında da söylenebilir. Nitekim, öğretide ${ }^{90}$, bu konuda en uygun yolun, tasfiye memurlarının ücret alacaklarının malvarlığının terki suretiyle konkordatoda belirlenmesi olduğu dile getirilmiştir. Esasen, İIK m. 298, I/4 uyarınca yargılama masrafları ile ilâm harçlarının borçlu tarafından mahkeme veznesine yatırılması, Türk hukukunda konkordatonun tasdik şartlarından biri olarak kabul edilmektedir. Tasfiye memurunun ücreti de konkordato masraflarına dahil olduğundan, bunların da tasdikten önce mahkeme veznesine yatırılması gerekir. Ödenecek ücretin miktarı da konkordatoda belirlenmelidir. Belirlenen bu ücret, tasdik makamı olan ticaret mahkemesinin onayına tâbidir. Ticaret mahkemesinin bu konuda gerekli gördüğü değişiklikleri yapması mümkündür. Mahkeme, değişiklik yaparken iflâs idaresi üyelerinin ücretlerinin belirlenmesine ilişkin olarak az önce bahsi geçen Tebliğ’i dikkate alabilir ${ }^{91}$.

Tasfiye memurlarının bir diğer hakkı ise istifa etme hakkıdır. Tasfiye memuru, kendisine önerilen görevi kabul etmek zorunda olmadığ1 gibi, göreve başladıktan sonra görevinden istifa etmesi de mümkündür. Fakat, bir kamu görevlisi sayılan, tasfiye memurunun istifasının görevini kesintiye uğratmaması gerekir. Bu nedenle gerekirse, yerine yenisi atanıncaya kadar, görevlerine devam etmeleri gerekir. Aksi halde, hukuki ve cezai yönden sorumlu tutulabilecekleri kabul edilmektedir ${ }^{92}$.

\section{KARARLARINA KARŞI GIDILLEBILECEK HUKUKî YOLLAR}

İ̇K m. 309/ç uyarınca konkordato tasfiye memurları, alacaklılar kurulunun nezaret ve denetime tâbidir. Konkordato tasfiye memurlarının malvarlığının paraya çevrilmesine ilişkin kararlarına ${ }^{93}$ karşı öğrenilmesinden itibaren yedi gün içinde alacaklılar kurulu nezdinde itiraz edilebilir ve bu kurulun kararlarına karşı da şikâyet yoluna başvurulabilir.

\footnotetext{
${ }^{90}$ Ercan, s. 284.

${ }^{91}$ Ercan, s. 284

${ }^{92}$ Ercan, s. 284.

${ }^{93}$ Alacaklılar kurulu ve tasfiye memurlarının itiraz yoluna konu olmayan ve aleyhinde genel mahkemede dava açılması (örneğin sıra cetveline karşı açılan davalar) gerekmeyen bütün kararlarına karşı doğrudan doğruya icra mahkemesinde nezdinde şikâyet yoluna müracaat edilecektir (Ludwig, s. 58-59; Schoder, s. 427; Erdönmez, s. 208).
} 
Mehaz İsviçre İcra ve İflâs Kanunu'nun 320. maddesinin ikinci fikrası uyarınca konkordato tasfiye memurlarının kararlarına karşı öğrenilmesinden itibaren on gün içinde alacaklılar kuruluna itiraz etmek mümkündür. Alacaklılar kurulunun vereceği karara karşı da şikâyet yoluna gidilebilmektedir $^{94}$. Buna karş1lı uygulamada konkordato tasfiye memurlarının tüm kararlarına karşı şikâyet yoluna başvurulduğu ve bu başvuruların incelendiği görülmektedir ${ }^{95}$.

İsviçre hukukunda, alacaklılar kurulunun, tasfiye memurlarının kararlarına iştirak etmeleri durumunda (örneğin paraya çevirme konusunda kurul rızasını bildirmişse ya da tasfiye memurlarını bağlayıcı bir talimat vermişse, bu durumda yapılacak şikâyetlerin doğrudan doğruya icra mahkemesine yönlendirilmesi gerektiği kabul edilmektedir ${ }^{96}$. İsviçre Federal Mahkemesi, tasfiye memurlarının önemli bir karar vermeleri gereken her durumda karar vermeden önce alacaklılar kuruluna danışma alışkanlıklarına set çekmeye çalışmıştır. Yüksek mahkeme, böylelikle İsv. İIK m. 316e, II'nin (İ̈K m. 309/ç, I) ölü bir hüküm haline gelmesini engellemek istemiştir. Buna karşılık uygulamada, İsviçre Federal Mahkemesi’nin teorik olarak doğru olan bu kararı takip edilmemiştir. Çünkü, uygulamada, konkordato tasfiye memurları ile alacaklılar kurulu arasındaki yakın işbirliğinin büyük bir avantaj teşkil ettiği; bu sayede itirazların incelenmesi suretiyle olası zaman kaybının daha baştan önlendiği gözlemlenmiştir ${ }^{97}$.

İptali istenen karar, alacaklılar kurulunun katılımıyla ya da onun talimatı üzerine alınmışsa bu durumda söz konusu itiraz yoluna başvurulamaz $^{98}$. İsviçre Federal Mahkemesi, alacaklılar kurulunun itiraz yoluna başvurulması üzerine hem hukuka hem de amaca uygunluk bakımından denetim yapılabileceğini kabul etmektedir ${ }^{99}$.

${ }^{94}$ İcra mahkemesi nezdinde şikâyet yoluna başvurmadan önce itiraz yolu tüketilmiş olmalıdır. Bkz. Walder, s. 392.

${ }^{95}$ B1SchK 1965, 51; 1963, 111; Schoder, 427; Papa, s. 49; Ludwig, s. 56.

${ }^{96}$ Ludwig, s. 56.

97 Ludwig, s. 56-57. Brand ise konkordato tasfiye memurlarının malvarlığının paraya çevrilmesine ilişkin olarak vermiş olduğu kararlara karşı tanınan itiraz yolunun tümüyle lüzumsuz bulduğunu ifade etmiştir. Bkz. Brand, s. 13 (Ludwig, s. 57 dn. 36a'dan naklen).

${ }^{98}$ BGE 85 III 175 vd.

99 BGE 85 III 175 vd. Kanunda alacaklılar kurulunun bu durumda hangi yargilama hükümlerini uygulayacağı konusunda bir hüküm bulunmamaktadır. Bununla birlikte alacaklılar kurulunun kamu gücüyle donatılmış bulunmasından hareket edilerek asgari 
Tasfiye memurlarını paraya çevirmeyle ilgili kararlarının icra mahkemesinden önce alacaklılar kurulu tarafindan incelemesi bazı faydalar sağlayabilir. Gerçekten, tasfiye memurlarının paraya çevirmeyle ilgili kararlarına karşı genelde takdir hakkının yerinde kullanılmadığı gerekçesiyle şikâyete başvurulduğundan, bu tür ihtilafların önce paraya çevirme konusunda uzmanlı sahibi alacaklılardan oluşan alacaklılar kurulu tarafindan incelenmesi somut olay hakkında daha isabetli kararlar verilmesini sağlayabilir. Ayrıca, satışla ilgili uyuşmazlıklar itiraz yoluyla çözüme kavuşturulduğu ölçüde icra mahkemesine yapılacak şikâyet başvuruları azalacak ve böylece mahkemelerin iş yükü azalacaktır ${ }^{100}$.

Alacaklılar, tasfiye memurlarının kararlarına karşı, bu kararların gerek kanuna aykırı olduğu gerekse hadiseye uygun olmadığı gerekçesiyle itiraz yoluna başvurulabilir ${ }^{101}$. Borçlunun tasfiye memurlarının paraya çevirmeyle ilgili kararlarına karşı hangi sebeplere dayanarak itiraz yoluna başvurabileceği ise tartışmalıdır. İsviçre Federal Mahkemesi, borçlunun sadece kararın kanuna aykırı olduğu gerekçesiyle itiraz yoluna başvurabileceğini; malvarlığı üzerindeki tasarruf yetkisini alacaklılara devreden borçlunun bundan böyle satış işlemlerinin hadiseye uygun olmadığını ileri süremeyeceğini kabul etmektedir ${ }^{102}$. Öğretide bazı yazarlar $^{103}$ bu kararı isabetli bulmuştur. Bu yazarlara göre tasfiye sonunda borçlarından kurtulacak olan borçluya, paraya çevirme kararının hadiseye aykırı olduğu gerekçesiyle itiraz yoluna başvuru hakkı tanınması anlamsızdır. Aksi görüşe göre ${ }^{104}$ ise borçlunun da hadiseye aykırılık gerekçesiyle itiraz yoluna başvurabilmesi gerektiğini savunmaktadır. Nihayet, bu konuda ileri sürülmüş özgün bir diğer görüşe göre ${ }^{105}$ bu konuda bir ayırım yapılması gerekmektedir. Buna göre, alacaklılar tasfiye neticesinde elde edemeyecekleri alacaklarından feragat ettiklerini bildirirler

yargılama ilkelerine uygun davranması gerektiği belirtilmektedir. Buna göre, alacaklılar kurulu, taraflara hukukî dinlenilme hakkı tanımak zorundadır ve kararlarını en azından kısaca gerekçelendirmek zorundadır. Bkz. Winkelmann/Lévy/Jeanneret/Merkt/Birchler, s. 2906.

${ }^{100}$ Gehler, s. 153-154; Sprecher, s. 292-293 (Erdönmez, s. 209'dan naklen).

${ }^{101}$ Sprecher, s. 296 (Erdönmez, s. 210'dan naklen).

102 BGE 85 III 180; 102 III 33.

103 Fritzsche/Walder-Bohner, s. 658; Gehler, s. 160 (Erdönmez, s. 210'dan naklen); Jaeger/Walder/Kull/Kottmann, s. 202; Winkelmann/Lévy/Jeanneret/Merkt, s. 2906.

${ }^{104}$ Ludwig, s. 58.

${ }^{105}$ Erdönmez, s. 210-211. 
ve bu husus konkordatoda belirtilirse, borçlu, tasfiye sona erince borçlarından tamamen kurtulur. Borçlunun bu ihtimalde paraya çevirmeye ilişkin kararın hadiseye aykırı olduğu gerekçesiyle itiraz yoluna başvurmasında hukukî bir yararı yoktur. Buna karşılık, alacaklılar tasfiye neticesinde elde edemedikleri alacaklarından feragat etmezlerse, alacaklılara kalan alacakları için bir aciz vesikası verilecek ve borçlu borçlarından tamamen kurtulamayacaktır. Bu ihtimalde borçlunun konkordato masasına giren mal ve hakların mümkün olduğunca yüksek bir bedelle satılmasında hukukî menfaati bulunmamaktadır. Onun için, borçlunun bu durumda tasfiye memurlarının paraya çevirmeyle ilgili kararlarına karşı hadiseye aykırılık gerekçesiyle itiraz yoluna başvurabileceği kabul edilebilir. Öte yandan itiraz yoluna konu olamayacak bazı kararlar da bulunmaktadır. Nitekim alacaklılar kurulunun tek başına veya tasfiye memurlarıyla birlikte aldığı kararlara karşı alacaklılar kurulu nezdinde itiraz yoluna gidilemez ${ }^{106}$. Paraya çevirmenin usulü ve zamanı tasfiye memurlarınca belirlendiğinden (IIIK m. 309e, II), kurulun kararlarına karşı icra mahkemesi nezdinde şikâyet yoluna gidilecektir ${ }^{107}$. Rehinli alacaklılar alacaklarının açık kalan kısmı için geçici dağıtmaya katılabilirler. Açık kalan meblağın ne olduğunu belirleyecek olanlar tasfiye memurlarıdır. İşte, tasfiye memurlarının bu konuda verdikleri kararlara karşı doğrudan doğruya şikâyet yoluna müracaat edilmesi gerekir (IIIK m. 309ç, I) ${ }^{108}$. Son olarak, tasfiye memurlarının hazırladığı pay cetveline karşı da itiraz değil şikâyet yoluna gidilmesi gerekir (İiK m. 309h, I, c. 2$)^{109}$.

Öğretide ${ }^{110}$ ayrıca, paylaştırmayı düzenleyen İIK m. 309h, I hükmünün dar yorumlanmaması gerektiği; tasfiye memurlarının pay cetveli düzenlemeden paylaştırma yapmaları veya pay cetvelini geç düzenlemeleri halinde de itiraz yoluna başvurabileceği; kurulun itiraz üzerine vereceği karara karşı ise şikâyet yoluna gidilebileceği ileri sürülmektedir. Aksi yöndeki görüşe göre ${ }^{111}$ ise kanunda tasfiye memurlarının sadece paraya çevirmeye ilişkin kararlarına karşı itiraz yoluna başvurulacağ öngörüldüğünden (İ̈K m. 309ç, I) bu görüsse katılmak mümkün değildir.

\footnotetext{
${ }^{106}$ Ludwig, s. 56.

107 Jaeger/Walder/Kull/Kottmann, s. 202.

108 Jaeger/Walder/Kull/Kottmann, s. 223.

109 Jaeger/Walder/Kull/Kottmann, s. 213.

${ }^{110}$ Winkelmann/Lévy/Jeanneret/Merkt, s. 2944.

${ }^{111}$ Erdönmez, s. 211 dn. 74.
} 
Kanımızca da bahsi geçen iki durumda itiraz değil; şikâyet yoluna başvurulması mümkündür. Birinci halde şikâyetin konusunu kanuna aykırılık; ikinci halde ise bir hakkın sebepsiz yere sürüncemede bırakılması oluşturacaktır.

İIK m. 309/ç, I'de bahsi geçen itiraz yolunun hukukî niteliğinin ne olduğu öğretide tartışmalıdır. Bir görüşe göre itiraz yolunun hukukî niteliği yeniden değerlendirme (Wiedererwägung ${ }^{112}$ ) değil, bir çeşit şikâyettir ${ }^{113}$. Zira burada işlemi yapan organın kendi işlemini yeniden değerlendirmesi değil, işlemin hukuka uygunluğunun bir üst merci tarafindan kontrol edilmesi söz konusudur. Dolayısıyla, alacaklılar kurulunun doğrudan kendisinin yaptığı işlemlere karşı veya İ̈K m. 309/e, II hükmünde olduğu gibi tasfiye memurları ile birlikte kararlaştırdığı işlemler için itiraz yoluna gidilebilmesi mümkün değildir. Bu işlemlere karşı ancak icra mahkemesine şikâyet yoluna başvurulabilir. İtiraz yolu şikâyetin yerine geçmemekte; aksine onu tamamlamaktadır. İtiraz yolu, şikâyet yoluna başvurmanın bir ön şartıdır. Bu nedenle itiraz yolu tüketilmeden şikâyet yoluna başvurulamaz ${ }^{114}$. Şu halde itiraz, en erken alacaklılar kurulunun paraya çevirme tarihini belirledikten sonra gündeme gelebilen ve tasfiye memurlarının paraya çevirmeye ilişkin işlemlerine karşı gidilmesi gereken, hukukî niteliği itibarıyla şikâyete benzeyen, ancak onun yerine geçmeyip onun bir ön şartı olan hukukî bir çare olarak tanımlanabilir ${ }^{115}$.

İsviçre hukuk öğretisinde alacaklılar kurulunun yapmış olduğu bu incelemenin faydalarına da işaret edilmiş ve tasfiye memurlarının işlemlerine genellikle paraya çevirme konusunda takdir haklarını yerinde kullanmadıkları için itiraz edildiğinden, bu itirazın icra mahkemesi yerine, paraya çevirme konusunda uzman ve dosyaya hâkim olan alacaklılar kurulu tarafindan incelenmesinin, somut olay hakkında daha isabetli kararlar verilmesini sağlayabileceği dile getirilmiştir. Keza, satışla ilgili uyuşmazlıklar, itiraz yoluyla çözüme kavuşturulduğu ölçüde icra mahkemesi nezdinde yapılacak şikâyet başvurularının da azalacağı belirtilmiştir ${ }^{116}$.

\footnotetext{
112 Örnek için bkz. Ercan, s. 291 dn. 159.

${ }^{113}$ Ludwig, s. 56; Sprecher, Nr. 1003 (Ercan, s. 292'den naklen); Gehler, s. 153 (Erdönmez, s. 209'dan naklen); Winkelmann/Lévy/Jeanneret/Merkt/Birchler, s. 2908.

${ }^{114}$ Sprecher, Nr. 1009 (Ercan, s. 292'den naklen); Erdönmez s. 208.

${ }^{115}$ Erdönmez, s. 208; Ercan, s. 292.

${ }^{116}$ Ludwig s. 56; Sprecher, Nr. 1005 (Ercan, s. 293'den naklen); Gehler, s. 153 (Erdönmez, s. 209'dan naklen).
} 
İtirazın konusu sadece tasfiye memurlarının paraya çevirmeye ilişkin işlemleridir (İ̈K m. 309/ç, I, c. 2). Tasfiye memurlarının, alacağı taşınır rehni ile güvence altına alınan rehinli alacaklıya, elinde bulundurduğu rehinli taşınırı paraya çevirmesi için süre vermesi (İ̈K m. 309/g, II), paraya çevirmeye ilişkin bir işlem olduğundan bu işleme karşı da itiraz yoluna başvurulabileceği gerek İsviçre ${ }^{117}$ gerek Türk hukuk öğretisinde ${ }^{118}$ kabul edilmektedir.

Tasfiye memurlarının bir işlemine karşı itiraz yoluna başvurulabilmesi için o işlemin alacaklılar kurulu ile birlikte yapılmamış olması gerekir. $\mathrm{Bu}$ cümleden olmak üzere, paraya çevirmenin usulü ve zamanını belirlemede olduğu gibi işlem, tasfiye memurları ile alacaklılar kurulu tarafindan birlikte yapılmışsa, bu işleme karşı sadece şikâyet yoluna başvurulabilir ${ }^{119}$. Buna rağmen böyle bir işleme karşı itiraz yoluna başvurulmuşsa, kurulun, inceleme yapmadan dosyayı icra mahkemesine göndermesi gerektiği kabul edilmektedir ${ }^{120}$.

İIK m. 16'da öngörülen şikâyet nedenleri itiraz için de geçerlidir. İtiraz merci olarak alacaklilar kurulunun bu konuda inceleme yetkisinde bir sınırlama bulunmamaktadır. Diğer deyişle, tasfiye memurlarının hem kanuna aykırı olan hem de hadiseye uygun olmayan işlemlerine karşı itiraz yoluna başvurulabilir $^{121}$. Bu bağlamda, paraya çevirmeye ilişkin bir işlemin tasfiye memurları tarafından yerine getirilmemesi veya nedensiz yere sürüncemede bırakılması halinde de itiraz yolu açıktır ${ }^{122}$.

İtiraz yoluna başvurmak isteyen tarafin bu yola başvurmakta hukukî yararının bulunması gerekir ${ }^{123} . \mathrm{Bu}$ bağlamda, tasfiye memurunun malvarlığının paraya çevirmesi işleminden dolayı zarar gören her ilgilinin, yani her bir alacaklının ve hatta borçlunun itiraz yoluna başvurabileceği kabul edilmektedir ${ }^{124}$.

\footnotetext{
${ }^{117}$ Winkelmann/Lévy/Jeanneret/Merkt/Birchler, s. 2906.

${ }^{118}$ Ercan, s. 293.

119 Winkelmann/Lévy/Jeanneret/Merkt/Birchler, s. 2906; Jaeger/Walder/Kull/Kottmann, s. 190; Sprecher, Nr. 1008 (Ercan, s. 294'den naklen); Ludwig, s. 56; Erdönmez, s. 211.

${ }^{120}$ Sprecher, Nr. 1008 (Ercan, s. 294'den naklen).

121 Winkelmann/Lévy/Jeanneret/Merkt/Birchler, s. 2906; Sprecher, Nr. 1009 (Ercan, s. 294'den naklen).

${ }^{122}$ Ercan, s. 294.

${ }^{123}$ Ercan, s. 294.

${ }^{124}$ Winkelmann/Lévy/Jeanneret/Merkt/Birchler, s. 2906; Ercan, s. 295.
} 
Borçlunun, tasfiye memurlarının paraya çevirmeye ilişkin işlemlerine karşı hangi nedenlere dayanarak itiraz yoluna başvurabileceği öğretide tartışmalıdır. İsviçre Federal Mahkemesi, borçlunun sadece kanuna aykırılık nedenine dayanarak itiraz yoluna başvurabileceği, buna karşılık, malvarlığ üzerindeki tasarruf yetkisini alacaklılara terk eden borçlunun artık işlemin hadiseye uygun olmamasından dolayı itiraz yoluna başvuramayacağı yönünde bir karar vermiştir. Öğretide bazı yazarlar ${ }^{125}$ bu kararı benimseyerek, malvarlığının tamamı veya bir kısmı üzerindeki tasarruf yetkisini alacaklılara terk eden borçlunun, artık bu malların paraya çevrilmesinin hadiseye uygun olup olmadığının belirlenmesi konusunda bir hukukî yararının olmadığını ileri sürmektedirler. Bu görüşe karşı Ludwig ${ }^{126}$, gerekçesini açıklamadan borçlunun işlemin hadiseye uygun olmamasından dolayı da itiraz yoluna başvurması gerektiğini dile getirmiştir. $D o k a^{127}$ ise borçlu tarafından itiraz edilecek paraya çevirme işlemlerinin çoğunlukla, onun için beklenilmeyen, kötü sonuçlar doğurabilecek nitelikteki takdire dayalı işlemler olduğunu dile getirerek bu görüşe karşı çıkmaktadır.

Ercan ise bu konuda alacaklıların konkordato ile karşılanmayan alacaklarından feragat etmiş olup olmadıklarına göre bir ayırım yapmak gerektiği yönünde özgün bir görüş ileri sürmüştür. alacaklılar, konkordato ile karşılanamayan alacaklarından feragat etmişlerse, borçlu, tasfiye sonucunda ödenmeyen borçlarından kurtulamayacaktır. Bu durumda, alacaklılara iflâsta olduğu gibi bir aciz belgesi verilir. Birinci ihtimalde, borçlunun paraya çevirmeye ilişkin işlemin hadiseye uygun olmamasından dolayı itiraz yoluna başvurmasında hukukî bir yararı yoktur. buna karşılık, ikinci ihtimalde, konkordato masasındaki malların olabildiğince yüksek bir bedelden satılmasında borçlunun da hukukî yararı vardır. bu nedenle, alacaklıların konkordato ile karşılanamayan alacaklarından feragat etmemiş olmaları durumunda, borçlunun tasfiye memurlarının paraya çevirmeye ilişkin bir işleminin hadiseye uygun olmamasından dolayı da itiraz yoluna başvurabilmesi gerekir ${ }^{128}$. Alacaklı ile borçlu dışında tasfiye memurlarının paraya çevirme işleminden zarar gören üçüncü kişilerin de itiraz yoluna

125 Gehler, s. 160-161; Winkelmann/Lévy/Jeanneret/Merkt/Birchler, s. 2906 Karş. Fritzsche/Walder-Bohner, s. 660. Yazarlara göre, paraya çevirmeye ilişkin salt takdiri konular, borçlu tarafindan icra mahkemesi önüne götürülemez.

${ }^{126}$ Ludwig, s. 58.

${ }^{127}$ Doka, s. 159

${ }^{128}$ Erdönmez, s. 211; Ercan, s. 295-296. 
başvurabilmeleri mümkündür ${ }^{129}$. İtiraz başvurusunun pasif tarafını tasfiye memuru teşkil eder ${ }^{130}$.

İiK m. 309/ç, I, c. 2 uyarınca konkordato tasfiye memuralırının malvarlığının paraya çevrilmesine ilişkin kararlarına karşı öğrenilmesinden itibaren yedi gün içinde alacaklılar kurulu nezdinde itiraz edilebilir ve bu kurulun kararlarına karşı da şikayet yoluna başvurulabilir. Acaba, tasfiye memurlarının malvarlığının paraya çevrilmesine ilişkin kararları dışındaki kararlarına karşı da şikâyet yoluna başvurulabilir mi, yoksa kanun koyucu burada soruya olumsuz cevap vermek amacıyla bilinçli olarak mı susmuştur? Aynı şey, mehaz İsv. İIKK m. 320, II hükmü bakımından da geçerlidir. İsviçre hukuk öğretisinde Hunkeler, şikâyet yoluna atıf yapılmamış olmasının kanun koyucunun muhakkak bilinçli olarak sustuğu anlamına gelmeyeceğini kanıtlamıştır ${ }^{131}$. Bu bakımdan şartlar gerçekleşmişse İIK m. 16 (İsv. İIKK m. 17) uyarınca şikâyet yoluna başvurulabileceği kabul edilmektedir ${ }^{132}$. Türk hukuku bakımından da aynı sonuca ulaşmak mümkündür ${ }^{133}$. Nitekim, bu konuda İ̈K m. 309/h, I, c. 2'de tasfiye memurlarının hazırlamış oldukları pay cetveline karşı şikayet yoluna başvurulabileceği açıkça düzenlemek suretiyle; tasfiye memurlarının malvarlığının paraya çevrilmesine ilişkin kararları dışında kalan kararlarının da şikayete tâbi olabileceğine dolaylı olarak işaret edilmiştir.

Alacaklılar kurulunun itiraz üzerine yapmış olduğu faaliyetin yargısal bir faaliyet olup olmadığ 1 tartışmalıdır. Bir görüsse göre ${ }^{134}$, alacaklılar kurulunun bu yetkisi yargısal bir nitelik taşımamaktadır. Zira sözü geçen yetki alacaklılar kurulunun denetim ve nezaret görevi çerçevesinde değerlendirilmelidir. Öte yandan, kurulun aleni bir yargılama faaliyeti yürütmemesi ve üyelerinin ücretlerinin devlet tarafindan değil, tasfiye neticesinde ele geçen paradan masa borcu olarak ödenmesi de onun yargısal bir fonksiyonu bulunmadığı anlamına gelir. Ayrıca kanunda, devletin alacaklılar kurulunun kurarlarından sorumlu olacağına dair bir hükmün bulunmaması da bu düşünceyi desteklemektedir (İ̈K m. 5; İsv. İ̈K m. 5). Diğer görüşe göre ise alacaklılar kurulunun yaptığı denetim yargısal

${ }^{129}$ Karş. Kuru/Arslan/Yılmaz, s. 71; Pekcanıtez/Atalay/Sungurtekin-Özkan/Özekes, s. 77; Ercan, s. 296.

${ }^{130}$ Erdönmez, s. 209; Ercan, s. 296.

${ }^{131}$ Hunkeler Kn. 1128 (Jaeger/Walder/Kull/Kottmann, s. 190-191'den naklen).

132 Jaeger/Walder/Kull/Kottmann, s. 191.

${ }^{133} \mathrm{Bu}$ yönde: Deliduman, s. 1055.

${ }^{134}$ Erdönmez, s. 202. 
niteliktedir ve bu yetki sayesinde, alacakl1lar kurulu, icra mahkemesinden önce bir ön mercii olarak görev yapmaktadır ${ }^{135}$. Kanımızca da alacaklılar kurulunun yapmış olduğu denetim, yargısal niteliktedir. Alacaklılar kurulu üyelerinin ücretlerini devletten almıyor olmaları onların yargısal bir faaliyette bulunmadıkları anlamına gelmez. Aksi halde, hakemlerin de yargisal faaliyette bulunmadıkları sonucuna varmak gerekirdi. Bundan başka, alacaklılar kurulu, önlerine gelen itiraza ilişkin olarak, taraflardan birinin talebi üzerine, yargısal usule uyularak ve iki tarafa iddia ve savunma hakkı tanınarak çözümlemektedirler. Bu nedenle yapmış oldukları faaliyetin yargisal olduğunu kabul etmek uygun olur. Nitekim öğretide, kanunda itiraz üzerine alacaklılar kurulunun uyması gereken yargilama ilkeleri hakkında herhangi bir düzenleme yer almaması karşısında bu konuda şikâyete ilişkin usul ilkelerini geçerli olması gerektiği ve bu bağlamda, alacaklılar kurulunun özellikle hukukî dinlenilme hakkı gibi yargılama ile ilgili temel ilkeleri gözetmesi ve kararını özet şeklinde de olsa gerekçelendirmesi gerektiği dile getirilmiştir ${ }^{136}$.

Alacaklılar kurulu, yaptığı inceleme sonucunda talebi yerinde görürse, ya itiraz konusu işlemin iptaline veya düzeltilmesine ya da tasfiye memurlarının yapmadıkları veya nedensiz yere sürüncemede bıraktıkları işlemin yapılmasına karar verir ${ }^{137}$.

\section{TASFIYE MEMURLARININ SORUMLULUĞU}

\section{HUKUKÎ SORUMLULUĞU}

İsviçre İcra ve İflâs Kanunu'nda 1994 yılında yapılan kanun değişikliği ile ${ }^{138}$ tasfiye memurlarının hukuka aykırı eylemlerinden Kantonların (Devletin) sorumlu olacağ 1 açıkça düzenlenmiştir (m. 5) ${ }^{139}$. Buna karşılık

\footnotetext{
${ }^{135}$ Yücel/Kale, s. 516.

${ }^{136}$ Winkelmann/Lévy/Jeanneret/Merkt/Birchler, s. 2907; Erdönmez, s. 212; Ercan, s. 296.

${ }^{137}$ Erdönmez, s. 212; Ercan, s. 297.

138 Daha önceden ise tasfiye memurlarının sorumluluğu İsv. İİK m. 316f ile özel olarak düzenlenmişti. Buna göre tasfiye memurları kusurları ile alacaklılara vermiş olduğu zararlardan dolayı İsv. İ̇K m. 5 çerçevesinde icra ve iflâs müdürleri gibi şahsen sorumlu idi. Bununla birlikte, icra ve iflâs müdürlerinin sorumluluğundan farklı olarak, tasfiye organları için devletin ikinci derecede sorumluluğu, devletin bunların seçiminde herhangi bir rol oynamadığı gerekçesiyle reddedilmekteydi. Bkz. Ludwig, s. 60; Kuru, İcra IV, s. 3883; Ercan, s. 286.

${ }^{139}$ İsv. İIK m. 5'de açıç̧a tasfiye memurlarından da bahsedilmiştir. Bahsi geçen madde ile icra ve iflâs işleri için devletin birinci derecede ve sebep sorumluluğu düzenlenmiştir.
} 
İcra ve İflâs Kanunu'nda bu konuda herhangi bir düzenleme yer almadığı gibi İIK m. 5'e atıfta da bulunulmamıştır. Buna rağmen, öğretide ${ }^{140}$, mehaz kanun esas alınarak, tasfiye memurlarının görevlerini yerine getirirken ya da yetkilerini kullanırken kusurlu tutum ve davranışlarıyla verdikleri zararlardan dolayı Devlet'in sorumluluğu yoluna gidilebileceği; ancak Devlet'in de kusurlu tasfiye memurlarına rücu hakkının saklı olduğu savunulmuştur (İ̈K m. 5) ${ }^{141}$.

Öğretide ${ }^{142}$ tasfiye memurlarının hukukî sorumlulukları belirlenirken iflâs idaresi üyelerinin hukukî sorumlulukları hakkında kabul edilen düzenlemelerden yararlanılabileceği; bu bağlamda İcra ve İflâs Kanunu'nun 227 nci maddesinde iflâs idaresi üyelerinin sorumluluğu konusunda daha önce 5 inci maddesine yollama yapılırken 3222 sayılı Kanun ile yapılan değişiklik sonucunda iflâs idaresi üyelerinin kusurlarından ileri gelen zararlardan dolayı kendilerinin sorumlu olacakları ve aleyhlerindeki davaların adliye mahkemelerinde açılabileceğinin hükme bağlanmış olduğu; konkordato komiserinin hukukî sorumluluğu konusunda 4949 sayılı Kanun değişikliğine kadar İcra ve İflâs Kanunu'nda bir düzenleme bulunmadığı ve $\mathrm{bu}$ dönemde konkordato komiserinin hukukî sorumluluğu hakkında Anayasa'nın 129 uncu maddesinin beşinci fikrası ile 40 incı maddesinin ikinci fikrası hükmünden yararlanılmak suretiyle devletin birinci derecede sorumlu olması gerektiğine işaret edildiği; fakat 4949 sayılı Kanun ile konkordato komiserinin kusurundan doğan zararlardan sorumlu olacağının açıkça hükme bağlanmış olduğu; yapılan bu kanun değişikliği ile kanun koyucunun icra ve iflâs dairesi görevlileri dışında kalan cebri icradaki diğer görevlilerin sorumluluğu konusundaki eğiliminin, onların kusurlarıyla yol açtıkları zararlardan bizzat sorumlu olmaları yönünde olduğu belirtilmiş ve bu çerçevede hukukî niteliği iflâs idaresi üyelerinin hukukî niteliği ile benzer olan tasfiye memurlarının da kusurlarından doğan zararlardan genel

\footnotetext{
Böylelikle, zarara uğrayan artık zarar verenin kusurunu ileri sürmekten kurtulmuştur. Bkz. Taşpınar, s. 604-605.

${ }^{140}$ Buna karşıllk görevleri itibarıyla konkordato tasfiye memurlarına benzetilen iflâs idaresi bakımından farklı bir görüş savunulmuştur. Bu görüşe göre iflâs idaresinin sorumluluğu bakımından İIK m. 227'de sadece $\mathrm{m}$. 5'e atıf yapılmış; m. 6'ya ise herhangi bir atıf yapılmamıştır. O nedenle iflâs idaresinin işlemlerinden dolayı devletin ikinci derecede dahi sorumlu tutulması mümkün değildir. Bkz. Yılmaz, İflâs İdaresi, s. 191.

${ }^{141}$ Yücel/Kale, s. 524-525.

${ }^{142}$ Ercan, s. 288.
} 
hükümler çerçevesinde (BK m. 41 vd.) sorumlu olmaları gerektiği sonucuna ulaşı1mıştır.

Anayasa'nın 40 ıncı maddesinin üçüncü fıkrasına göre kişinin, resmi görevliler tarafından vaki haksız işlemler sonucu uğradığı zarar da, kanuna göre, devletçe tazmin edilir. Devletin sorumlu olan ilgili görevliye rücu hakkı saklıdır. Anayasa'nın 129 uncu maddesinin beşinci fikrasına göre memurlar ve diğer kamu görevlilerinin yetkilerini kullanırken işledikleri kusurlardan doğan tazminat davaları, kendilerine rücu edilmek kaydıyla ve kanunun gösterdiği şekil ve şartlara uygun olarak, ancak idare aleyhine açı1ır. Konkordato tasfiye memurlarının da tıpkı konkordato komiseri gibi resmi görevli olarak kamu hizmeti ifa ettikleri dikkate alındığında onların hukuka aykırı eylemlerinden dolayı da devletin sorumlu tutulması mümkündür. Devletin sorumluluğunun doğması için gerçekleşmesi gereken şartlar, Anayasa'nın 40 inc1 maddesinin üçüncü ve 129 uncu maddesinin beşinci fikralarında öngörülen düzenlemeler dikkate alındığında şu şekilde sıralanabilir: 1) Hukuka aykırılık, 2) Kusur, 3) Zarar, 4) İlliyet bağ ${ }_{1}^{143}$.

Alacaklılar kurulunun nihai raporu onaylamasının tasfiye memurlarının ibra edilmeleri sonucunu doğuracak mıdır? Konu öğretide tartışmalıdır. Bazı yazarlar $^{144}$, alacaklılar kurulunun nihai raporu onaylamasının tasfiye memurlarının ibra edilmeleri sonucunu doğurduğunu ve alacaklıların bundan böyle nihai raporda belirtilen işlemlerden dolayı tasfiye memurlarının sorumlu tutulamayacaklarını savunmaktadır. Aksi yöndeki görüşü savunan yazarlara göre ${ }^{145}$ ise nihai raporun alacaklılar kurulu tarafindan onaylanmasının tasfiyeye katılan alacaklılar bakımından bağlayıcı olmadığı kabul edilmelidir. Aksi takdirde alacakl1lar kurulu tarafindan onaylanan nihai raporun alacaklıların incelemesine sunulacağını (İ̈K m. 309j, I); alacaklıların tasfiye memurlarının işlemleri hakkında ancak yapacakları bu inceleme sonucunda bir kanaat edineceklerini; nihai raporun onaylanmasının ibra niteliğinde olduğu ve alacaklıların bundan böyle tasfiye memurlarına karşı dava açamayacakları kabul edilirse, alacaklılara inceleme yetkisi tanınmasının bir anlamı kalmaz.

${ }^{143}$ Konkordato komiseri bakımından bkz. Tanrıver, s. 270 vd.

${ }^{144}$ Jaeger/Walder/Kull/Kottmann, s. 230.

${ }^{145}$ Sprecher, s. 303 (Erdönmez, s. 219'dan naklen). 


\section{CEZAî SORUMLULUĞU}

İcra ve İflâs Kanunu'nda iflâs idaresini teşkil edenlerin TCK uygulamasında memur sayılacakları açıkça belirtilmişken (m. 227, V), konkordato tasfiye memurları hakkında bir açıklık söz konusu değildir. Yukarıda da çeşitli kereler belirtildiği gibi tasfiye memurları ifa ettikleri görev dikkate alındığında en çok iflâs idaresi memurlarına yaklaşmaktadırlar. O nedenle iflâs idaresi memurlarının ceza kanunu anlamında kamu görevlisi (memur) sayılıp sayılmadıkları hakkında daha önce yürütülmüş bulunan tartışmalar tasfiye memurlarının ceza kanunu anlamında kamu görevlisi sayılıp sayılmadıklarının tespiti bakımından önem taşımaktadır ${ }^{146}$. Eski Türk Ceza Kanunu zamanında iflâs idaresi memurlarının ceza kanunu anlamında memur sayılıp sayılmayacakları, 1985 yılında 322 sayılı Kanun ile yapılan değişikliğe kadar $^{147} \operatorname{tartışmalı~idi~}^{148}$. Söz konusu değişiklikten önce ileri sürülen bir görüşe göre ${ }^{149}$ iflâs idaresi memurlar1, Eski Ceza Kanunu m. 279'daki "muvakkat, ücretli ve ihtiyari olarak adli bir amme vazifesi gören diğer kimseler" tarifine girdiğinden ceza kanunu anlamında kamu görevlisi (memur) sayılması gerekmekteydi. Zira devletle arasında bir istihdam bağı bulunmayan bir kimsenin ceza kanunun uygulanmasında memur sayılması için gereken şu şartlar iflâs idare memurları bakımından da mevcuttu: a) Özel bir kişinin bir kamu görevini

\footnotetext{
${ }^{146}$ Konkordato komiserlerinin cezai sorumluluğu hakkında da 4949 sayılı Kanunu'nun 92 nci maddesi ile eklenen 334/a hükmüne kadar mevzuatımızda herhangi bir düzenleme yer almamaktaydı ve öğretide konkordato komiserinin eski Türk Ceza Kanunu anlamında memur sayılıp sayılmayacağı tartışmalı idi. Postacıŏglu (s. 70) ve Tanrıver'e göre (s. 275 vd.), konkordato komiseri eski Türk Ceza Kanunu anlamında memurdu. Kuru'ya göre ise (İflâs s. 409 dn. 113) memur değildi. 4949 say1lı Kanunu'nun (RG 30.7.2003, sa. 25184) 92 nci maddesiyle eklenen İ̈K m. 334/a uyarınca konkordato komiserlerinin, işledikleri eylemler bakımından Türk Ceza Kanunu'nun 279 uncu maddesi anlamında memur sayılacakları hükme bağlanmıştı. Bahsi geçen Kanun'dan kısa süre sonra kabul edilen 5358 sayılı Kanun'un (RG 1.6.2005, sa. 25832) 21 inci maddesi ile İIK m. 334/a hükmü kaldırıldı. Buna gerekçe olarak kaldırılan hükmün yeni Türk Ceza Kanunu'nun sistemine uymaması gösterilmiştir. Kanımızca, konkordato komiseri, yürürlükteki mevzuat dikkate alındığında, yeni Türk Ceza Kanunu'nun 6 ncı maddesinin 1 inci fikrasının c bendinde bahsi geçen kamu görevlisi olarak nitelendirilebilir.

${ }^{147}$ Bkz. RG 15.6.1985, sa. 18785.

148 Kanımızca 5358 say1l Kanun'un 21 inci maddesiyle İIK m. 227, V hükmü de kaldırılmalıydı. Zira bahsi geçen maddenin gerekçesinde belirtilenler iflas idaresi memuru bakımından da geçerli olmalıdır. Bkz. dn. 140 altındaki açıklamalar.

${ }^{149}$ Erman, S.: Ceza Tatbikat ve Tâkibatında Memur (SBOD 1947/1-2), s. 269; Erman, İflâs İdaresi Memurları, s. 31.
} 
yerine getirmesine bir kanun hükmünün olanak tanıması. b) Devletle, kamu hizmetinin yerine getirilmesine katılan fert arasında bir kamu hukuku ilişki ve bağının kurulmuş olması. c) Fert tarafından yapılan faaliyetin bir kamu görevi niteliğinde olması. Karşı görüşteki yazarlara göre ${ }^{150}$ ise yapmış oldukları işler dikkate alındığında iflâs idaresi memurlarının eski Ceza Kanunu m. 279 anlamında memur sayılmaları mümkün değildi. Zira bu görüştekilere göre, iflâs idaresinin görevlerine giren hususların kamu gücünün kullanılmasıyla bir ilgisi bulunmamaktadır.

Yeni Türk Ceza Kanunu'nun kabulünden sonra, tasfiye memurlarının cezaî sorumluluğunun tespiti konusunda öncelikle üzerinde durulması gereken, onların eski Türk Ceza Kanunu m. 279'a denk düşen yeni m. 6/1-c hükmü karşısında kamu görevlisi sayılıp sayılmayacaklarıdır. Bahsi geçen hükme göre, "kamu görevlisi deyiminden; kamusal faaliyetin yürütülmesine atama veya seçilme yoluyla ya da herhangi bir surette sürekli, süreli veya geçici olarak katılan kişi” anlaşılmaktadır. O halde, kimlerin kamu görevlisi sayılacağı konusuna açıklık getirmek için öncelikle "kamusal faaliyet" kavramının aydınlığa kavuşturulması gerekmektedir. Bunun için ifa edilen görevin amacını, fonksiyonun niteliğini dikkate almak gerekir. Buna göre devletin yerine getirmek zorunda olduğu asli görevleri yapanlar kamu görevlisidirler. Kamu otoritesi adına yürütülen bir faaliyetin icrasına kamu hukuku usulüne göre (AY m. 128'deki ifadesiyle "genel idare esaslarına göre") katılan herkes, kamu görevlisidir ${ }^{151}$. Bu bakımdan ölçüt, görülen işin bir kamusal faaliyet olmasıdır. Bunun anlamı ise Anayasa ve kanunlarda belirlenmiş olan usullere göre verilmiş olan bir siyasal kararla, bir hizmetin kamu adına yürütülmesidir ${ }^{152}$. Bütün bu açıklamalar ve yukarıda konkordato tasfiye memurlarının hukukî nitelikleri açıklanırken verilen bilgiler ile görevi itibarıyla konkordato tasfiye memurlarına büyük benzerlik gösteren iflâs idaresi üyelerinin Türk Ceza Kanunu anlamında memur sayılacaklarına ilişkin İ̈K m. 227, V hükmü dikkate alındığında onların da kamusal bir faaliyeti devlet yerine geçici olarak icra eden kamu görevlisi olduklarının

\footnotetext{
${ }^{150}$ Postacioğlu, s. 62; Postacioğlu, İ.: Türk Ceza Kanunu Muvacehesinde İflâs İdare Memurları (İ̈̈HFM 1973/1-4), s. 213; Şekercioğlu, s. 24.

${ }^{151}$ Tezcan, D./Erdem, M. R./Önok, R. M.: Ceza Özel Hukuku, Ankara 2006, s. 621.

152 Tercan/Erdem/Önok, s. 621. Kamusal faaliyetin unsurları öğretide şu şekilde sıralanmaktadır: a. Kamu adına yürütülen bir hizmetin bulunması, b. Hizmetin kuruluşunun yasaya ve siyasi iradeye dayanması, c. Hizmetin yürütülmesinde kamu erkinin (otoritesinin) kullanılması. Bkz. Gökcan/Artuç, s. 34 vd.
} 
kabulü gerekir. Bunun doğal bir sonucu olarak da onların görevi ihmal ve görevi kötüye kullanma suçlarını işlemeleri de mümkün hale gelecektir ${ }^{153}$.

\section{DISIIPLIN SORUMLULUĞU}

İcra ve İflâs Kanunu'nda tasfiye memurlarının disiplin sorumluluğu hakkında herhangi bir düzenlemeye yer verilmemiştir. Buna karşıllk, mehaz İsviçre İcra ve İflâs Kanunu'nun 320 nci maddesinin ikinci fikrasında icra ve iflâs memurlarının icra mahkemesinin disiplin yetkisine tâbi olduklarına ilişkin 14 üncü maddeye atıfta bulunulmuştur ${ }^{154} . \mathrm{Bu}$ nedenle İsviçre hukukunda icra mahkemesinin tasfiye memurları üzerinde disiplin yetkisine sahip olduğu konusunda herhangi bir tereddüt yaşanmamaktadır ${ }^{155}$.

Türk hukukundaki bu düzenleme boşluğu konkordato komiseri ve iflâs idaresi memurları bakımından da geçerlidir. O bakımdan bu konuda ileri sürülen görüşlere kısaca göz atmak tasfiye memurlarının disiplin sorumluluğunun tespiti bakımından faydalı olacaktır. Konkordato komiseri bakımından onu atayan organ durumunda bulunan icra mahkemesinin aynı zamanda onun tâbi olduğu asli denetim mercii olduğundan yola çıkılarak, icra mahkemesinin gerektiğinde komiseri resen ya da konkordato ilgililerinin veya konkordato prosedürü içinde görevli diğer makamların bildirimi üzerine görevden alabileceği (azledebileceği); icra mahkemesinin bu yetkisini, özellikle komiserin görevinin icrası sırasında yanlı hareket etmesi, görevini ve yetkilerini kötüye kullanması, konkordato prosedürü içerisinde üstlenmiş olduğu resmi görevle çelişir nitelik taşıyan tutum ve davranışlar sergileyen konkordato komiserine, eyleminin ağırlı̆̆ını ve niteliğini göz önünde bulundurarak, komiserlik ücretinin takdiri konusunda kendisine tanınan yetkiye dayanarak ücret kesintisi de uygulayabileceği; bunun yanı sıra, icra mahkemesinin, komisere, görevini yerine getirirken daha dikkatli

\footnotetext{
${ }^{153}$ Yücel/Kale, s. 525.

${ }^{154}$ Böylesi bir atfın yapılmamış olduğu önceki düzenleme zamanında da konkordato tasfiye memurlarının resmi bir görev ifa ettikleri gerekçesiyle onlar üzerinde de resmi bir denetim yapılması gerektiğini kabul ediliyordu. Fakat bu denetimin konkordato mercii tarafından mı yoksa icra mahkemesi tarafından mı yerine getirileceği tartışmalı idi. Bu konuda uzun süren belirsizlikten sonra İsviçre Federal Mahkemesi tavrını, vermiş olduğu 81 III 27 sayılı kararla icra mahkemesinden yana koymuştu. Bkz. Ludwig, s. 61.

${ }^{155} \mathrm{Jaeger} /$ Walder/Kull/Kottmann, s. 188; Winkelmann/Lévy/Jeanneret/Merkt/Birchler, s. 2872; Ercan, s. 290.
} 
davranması gerektiğini; aksi takdirde görevinden alınacağını ya da ücretinden kesinti yapılacağı ihtarında bulunulabileceği ifade edilmiştir. ${ }^{156}$

İflâs idaresi memurları bakımından da icra mahkemesinin gerekli hallerde iflâs idaresini görevinden uzaklaştırma (azletme) yetkisinin varlığından yola çıkılarak, aynı merciin daha hafif olan disiplin cezalarını verme yetkisine de sahip olduğu kabul edilmektedir ${ }^{157}$.

Yukarıda tasfiye memurlarının hukukî niteliği belirlenirken onların kamu hizmeti ifa eden kamu görevlileri oldukları ifade edilmişti. Tasfiye memurlar1, esasen devletin yerine getirmesi gereken bir adli hizmeti onun yerine ifa ettiklerinden onların bu görevlerinde denetim ve gözetimden muaf tutulmuş oldukları asla kabul edilemez. Tartışma konusu olan bu denetim ve gözetim yetkisinin mevcut olup olmadığı değil; bunun hangi mercii tarafindan yerine getirileceğidir. Bu konuda, daha önce, İsviçre hukukunda uzun süre yaşanan belirsizlikten sonra ${ }^{158}$ İsviçre Federal Mahkemesi, tavrını icra mahkemesinden yana koymuştu. Türk hukuku bakımından da 309/a, II c. 3 uyarınca konkordato tasfiye memurunun, icra mahkemesinin seçime ilişkin kararı onaylamasından sonra başlayacağına ilişkin hüküm göz önünde bulundurulduğunda aynı sonuca ulaşmak gerekir.

\section{SONUÇ}

Malvarlığının terki suretiyle konkordato ismine rağmen adi konkordatodan ziyade İflâsa yaklaşmaktadır. Çünkü kurumun temelindeki düşünce, borçlunun mali durumunu düzeltmek değil; mevcudunu en avantajlı bir şekilde paraya çevirerek alacaklıların alacaklarına kavuşmalarını sağlamaktır. Adi konkordatoda olduğu gibi malvarlığının terki suretiyle konkordatoda da korunması gereken menfaatler sadece borçlunun ve alacaklıların menfaati olmayıp; devlete, yani kamuya ait menfaatler de buraya dahildir. Bireylere ait menfaatler korunması ve uzlaştırılması ile toplumsal menfaatlerin dengelenmesine ve düzenlenmesine ve bu suretle kamu düzeninin sağlanmasına hizmet eden konkordato tasfiye memuru kamu yararına dayalı bir görev yapmaktadır ve hukuki niteliği itibarıyla AY m. 128, I'de geçen kamu görevlilerindendir.

\footnotetext{
${ }^{156}$ Bkz. Tanriver, s. 274.

${ }^{157}$ Geniş bilgi için bkz. Y1lmaz, İflâs İdaresi, s. 184-186.

${ }^{158} \mathrm{Bu}$ belirsizliğin sebebi 1994 yılında yapılan kanun değişikliğinden önce şimdiki 320 nci maddeye karşılık gelen 316e maddesinde icra ve iflâs memurlarının sorumluluğunu düzenleyen 14 üncü maddeye doğrudan bir atıf yapılmamış olması idi.
} 
Anayasa'nın 40 1ncı maddesinin üçüncü fikrasına göre kişinin, resmi görevliler tarafından vaki haksız işlemler sonucu uğradığı zarar da, kanuna göre, devletçe tazmin edilir. Devletin sorumlu olan ilgili görevliye rücu hakkı saklıdır. Anayasa'nın 129 uncu maddesinin beşinci fikrasına göre memurlar ve diğer kamu görevlilerinin yetkilerini kullanırken işledikleri kusurlardan doğan tazminat davaları, kendilerine rücu edilmek kaydıyla ve kanunun gösterdiği şekil ve şartlara uygun olarak, ancak idare aleyhine açılır. Konkordato tasfiye memurlarının da tıpkı konkordato komiseri gibi resmi görevli olarak kamu hizmeti ifa ettikleri dikkate alındığında onların hukuka aykırı eylemlerinden dolayı da devletin sorumlu tutulması mümkündür.

Yeni Türk Ceza Kanunu m. 6/1-c hükmü uyarınca "kamu görevlisi deyiminden kamusal faaliyetin yürütülmesine atama veya seçilme yoluyla ya da herhangi bir surette sürekli, süreli veya geçici olarak katılan kişi" anlaşılır. Tasfiye memurları da bu niteliklere sahip olduğundan ceza kanunu anlamında kamu görevlisi sayılırlar.

Tasfiye memurlarının disiplin sorumluluğu hakkında da tıpkı İflâs idaresi memurları ve konkordato komiserleri hakkında olduğu gibi Kanun'da herhangi bir düzenlemeye yer verilmemiştir. Ancak mehaz İsviçre İ̈K m. 320 ile m. 14'e yapılan atıf ile tasfiye memurlarının birer kamu hizmeti ifa eden kamu görevlileri oldukları göz önünde bulundurulduğunda onların da icra mahkemesinin disiplin yetkisine tâbi oldukları sonucuna varmak gerekir. 


\section{KAYNAKÇA}

Altay, S. (1993). Konkordato Hukuku. İstanbul.

Atalay, O. (2003). Konkordato Hukukundaki Değişiklikler. Bankacılar Dergisi, 2003/47, s. 99 vd.

Balta, T. B. (1970-1972). İdare Hukuku I, Genel Konular. Ankara.

Berkin, N. (1949). Konkordatoda Akdi ve Konkordatonun Hukukî Mahiyeti. IBD 1949/4, s. 193-213.

Böni. W. (1959). Die Massenverbindlichkeiten im Nachlassvertrag mit Vermögensabtretung. Freiburg.

Buruloğlu, E. / Reyna, Y. (1968). Konkordato Hukuku ve Tatbikat. İstanbul.

Coradi, A. (1973). Der Sachwalter im Gerichtlichen Nachlassverfahren nach Art. 293 ff. SchKG, Zürich.

Deliduman, S. (2004). Malvarlığının Terki Suretiyle Konkordato. IBD, 2004/3, s. $1032-1058$

Deren-Yıldırım, N. (1996). Türk, İsviçre ve Alman Medeni Usul Hukukunda Kesin Hükmün Sübjektif Sinırları. İstanbul.

Doka, C. (1926). Nachlassvertag mit Vermögensabtretung ZSR 1926/45, s. $126 \mathrm{vd}$.

Duran, L. (1986). Anayasa Mahkemesi'ne Göre Türkiye'nin Hukuk Düzeni II. $O A I D, 1986 / 18$, s. $17-28$.

Ercan, İ. (2008). İcra ve Iflâs Hukukunda Mal Varlı̆̆ının Terki Suretiyle Konkordato. Konya.

Erdönmez, G. (2003). Malvarlığının Terki Suretiyle Konkordatoda Alacaklılar Kurulunun Görev ve Yetkileri. GÜHFD, 2003/1, s. 199222.

Erman, S. (1947). Ceza Tatbikat ve Takibatında Memur. SBFD, 1947/3-4, s. 235-276.

Erman, S. (1975). İflâs İdaresi Memurları Ceza Kanunu'nun Tatbikinde Memurdurlar. İUHFM 1975/3-4, s. $31 \mathrm{vd.}$ 
Fritsche, H. / Walder Bohner, H. U. (1993). Schuldbetreibung und Konkurs nach schweizerischem Recht, Band II, Zurich.

Giavonoli, S. (1952). Der Nachlassvertarg mit Vermögönsabtretung nach dem revidierten Recht. BlSchK, 1952/4, s. 97-110.

Glarner, H. (1967). Das Nachlassvertragsrecht nach schweizerischen SchKG, Zürich.

Gökcan, H. T. / Artuç, M. (2007). Ceza ve Usul Hukukunda Kamu Görevlisi Kavramı ve Özel Soruşturma Usulleri. Ankara.

Gözler, K. (2005). İdare Hukuku Dersleri. Bursa.

Günday, M. (2004). İdare Hukuku. Ankara.

Haab, R. (1935). Die Bedeutung der Verordnung über das Nachlassverfahren von Banken und Sparkessen vom 11. April 1935 für die Praxis. Festgabe zum siebzigsten geburtstage von Fritz Goetzinger. Basel, s. $128 \mathrm{vd}$.

Haberthür B. (1950). Zur Revision des Schuldbetreibungs-und Konkursgesetzes, V. Teil, Der Nachlassvertrag, Abhandlung. BlSchK 1950/3, s. 66-82.

İyilikli, A. C. (2004). Malvarlığının Terki Suretiyle Konkordatonun Lex Commisoria Yasağına Aykırılık Teşkil Edip Etmemesi Üzerine Bir İnceleme Legal HD, s. 591-600.

Jaeger, C. / Walder, H.U. / Kull, T. M. / Kottmann, M. (1997/2001). Bundesgesetz über Schuldbetreibung und Konkurs (SchKG), Band: III, Art. 317, N. 7, Zurich.

Kanlıgöz, C. (1993). 1982 Anayasasına Göre Kamu Görevlisi Kavramının Kapsamı ve Anlam1. AÜHFD 1993/1-4, s. 169-196.

Kuru, B. (1963). Mevcudun Terki Suretiyle Konkordato. Banka ve Ticaret Hukuku Enstitüsünün Düzenlediği İcra ve İflâs Kanunu Değişiklik Tasarısı Hakkında Seminer. Ankara, s. 117 vd.

Kuru, B. (1997). İcra ve İflâs Hukuku. C. IV, İstanbul.

Kuru, B. (2004). İcra ve İflâs Hukuku, El Kitabl, İstanbul. 
Kuru, B. / Arslan, R. / Yılmaz, E. (2008). İcra ve İflâs Hukuku Ders Kitabı. Ankara.

Ludwig, P. (1970). Der Nachlassvertrag mit Vermögensabtretung (Liquidiations vergleich), Bern 1970.

Muşul, T. (2002). İcra ve İflâs Hukuku II. İstanbul.

Öztan, B. (1970). Medeni Hukuk Tüzel Kişilerinde Organ Kavramı ve Organın Fiillerinden Doğan Sorumluluk, Ankara.

Papa, G. (1941). Die analoge Anwendung der Konkursnormen auf den Nachlassvertrag mit Vermögensabtretung. Bern.

Pekcanitez, H. (1986). İcra-İflâs Hukukunda Şikâyet. Ankara.

Pekcanıtez. H. / Atalay, O. /Sungurtekin Özkan, M. / Özekes, M. (2007). İcra ve İflâs Hukuku. Ankara.

Postacioğlu, İ. (1965). Konkordato, İstanbul.

Postacioğlu, İ. (1973). Türk Ceza Kanunu Muvacehesinde İflâs İdare Memurları. ÏUHFM 1973/1-4, s. 207-220.

Schoch, H. (1940). Die juristische Natur der Pfändung und der Vermögensbeschlagnahme im Konkurs. Zürich.

Schoder, A. (1952). Der Nachlassvertag mit Vermögensabtretung ZBJV (88), s. $409 \mathrm{vd}$.

Şekercioğlu, M. (1974). Ceza Hukukumuzda Memur Kavramı. İstanbul.

Tanrıver, S. (1993). Konkordato Komiseri. Ankara.

Tanrıver, S. (2004). 4949 Sayılı İcra ve İflâs Kanunu'nda Değişiklik Yapılmasına Dair Kanun'un Adi Konkordato ile İlgili Hükümlerde Getirmiş Olduğu Değişikliklerin Tespiti ve Değerlendirilmesi. TBBD 2004/51, s. 67-80.

Tanrıver, S. / Deynekli, A. (1986). Konkordatonun Tasdiki. Ankara.

Taşpınar, S. (2004). İsviçre Fedaral İcra ve İflâs Kanunda Yapılan Değişikliklere Genel Bir Bakış. 75. Yaş Günü Iç̧in Prof. Dr. Baki Kuru Armă̆anı. Ankara, s. 599 vd. 
Tercan, E. (2006). Medeni Usul Hukukunda Eski Hale Getirme. Ankara.

Tevetoğlu, M. (2006). Malvarlığının Terki Suretiyle Konkordato. Legal MHD, s. 929-947.

Tezcan, D. / Erdem, M. R. / Önok, R. M. (2006). Ceza Özel Hukuku, Ankara.

Tschan, A. (1955). Der Naclassvertag mit Vermögensabtretung (Liquidations vergleich) in der Praxis, Abhandlung. BlSchK 1955/2, s. 33-44.

Umar, B. (1973). İcra ve İflâs Hukukunun Tarihî Gelişmesi ve Genel Teorisi. İzmir.

Üstündağ, S. (2002). İflâs Hukuku. İstanbul.

Ulukapı, Ö. (1998). Konkordatonun Feshi. Konya.

Walder, H. U. (2007). Schuldbetreibung und Konkurs. Zürich.

Winkelmann, A. / Lévy, L. / Jeanneret, V. / Merkt, O. / Birchler, F. (1998). Kommentar zum Bundesgesetz über Schuldbetreibung und Konkurs SchKG (Winkelmann / Levy / Jeanneret / Merkt) Band III. Basel / Gent / München.

Yayla, Y. (1985). İdare Hukuku. İstanbul.

Y1lmaz, E. (1976). İflâs İdaresi. Ankara (Y1lmaz, İflâs İdaresi).

Yılmaz, E. (1984). İflâs İdaresinin Hukukî Niteliği ve Durumu. İflâsta Tasfiye Sempozyumu. Ankara, s. 65 vd. (Y1lmaz, Sempozyum).

Yücel, M. T. / Kale, S. (2007). Malvarlığının Terki Suretiyle Konkordatoda Prosedür ve Yetkili Organlar. Prof. Dr. Yavuz Alangoya için Armağan. İstanbul, s. 503-541. 